\title{
Seasonal change in acclimatised respiration rate of Temora longicornis
}

\author{
Claudia Castellani ${ }^{1, *}$, Yener Altunbaş ${ }^{2}$
}

\author{
${ }^{1}$ Sir Alistair Hardy Foundation for Ocean Science (SAHFOS), Citadel Hill, Plymouth, PL1 2PB, Devon, UK \\ ${ }^{2}$ BBS, University of Bangor, College Road, LL57 2DG, Bangor, Gwynedd, North Wales, UK \\ *: Corresponding author : Claudia Castellani, email address, cxc@sahfos.ac.uk
}

\begin{abstract}
:
We investigated the seasonal changes in the respiration rate $(R)$ of adult Temora longicornis (Müller) acclimatised to in situ conditions over $1 \mathrm{yr}$. Mean ( $\pm 1 \mathrm{SE}) R$ varied from $50.5 \pm 2.8 \mathrm{nl} \mathrm{O}_{2}$ ind. $^{-1} \mathrm{~h}^{-1}$ in December to $73.2 \pm 3.53 \mathrm{nl} \mathrm{O}_{2}$ ind..$^{-1} \mathrm{~h}^{-1}$ in August for copepods of mean body dry weight (DW) of 33.5 \pm 1.1 and $26.3 \pm 0.95 \mu \mathrm{g}$, respectively. Males represented $\sim 8 \%$ of the total measurements, and their respiration did not differ significantly from that of females. $R$ scaled isometrically with dry weight (DW), i.e. the allometric exponent of the power function $\left(R=a \mathrm{DW} W^{b}\right)$ did not differ significantly from unity $(b=$ 0.83 to 1.35). The relationship between in situ weight-specific respiration rate $\left(R_{\mathrm{sp}}\right)$ and temperature ( $T$ ) was described by a sigmoid trend with $Q_{10}$ ranging from 1 to 2.88 (mean 1.57 to 1.89). In contrast, the acclimated and acutely measured $R_{\mathrm{sp}}$ of copepods maintained under optimal feeding conditions in the laboratory increased exponentially with temperature and were characterised by higher mean $Q_{10}$ of 2.05 and 2.41 , respectively. Acclimatised In $R$ increased significantly with In DW, $T$, In chlorophyll a (In $\mathrm{Chl}$ ) and In egg production rate (In EPR). Our results indicate that seasonal changes in $T$. longicornis respiration rate are not simply determined by body mass and temperature but also reflect copepod nutritional and reproductive condition. We argue that predictive ecological models using fixed thermal coefficient values may overestimate copepod respiration, particularly under ambient conditions limiting growth and reproduction. Our findings have important implications for the calculation of carbon flow in marine food-webs and for understanding how zooplankton physiology responds to changes in global temperature.
\end{abstract}

Keywords: Temora longicornis; Respiration; Acclimatisation; Acute rate ; Temperature ; Reproduction 


\section{Introduction}

Respiration is a fundamental property of organisms and ultimately it represents the main energy loss pathway within ecological systems. Thus, as the most abundant and diverse aquatic metazoan marine copepods play an important role, through their respiration, in shaping the structure and dynamics of food-webs and the flow of carbon in the ocean. Therefore, knowledge of how copepod respiration changes with in situ conditions is central to understanding the mechanisms determining community diversity, secondary production and biogeochemical cycles in the ocean.

In temperate latitudes, copepods experience considerable fluctuation in ambient conditions over the seasonal cycle which exerts a profound effect on their metabolism (e.g. Mauchline 1998). In copepod, as in poikilotherm in general, respiration rate is considered to vary mainly as a function of body mass and ambient temperature (Peters 1986, Ikeda et al. 2001, Brown et al. 2004). Published data, however, suggest that other factors, such as, food quantity, food quality and temperature acclimatisation are also important (Conover 1959, Conover \& Corner 1968, Marshall \& Orr 1958 \& 1966, Butler et al. 1970, Gaudy 1973). Respiration is also closely coupled with growth and reproduction (Mc Neill and Lawton 1970) both of which can represent a substantial energetic cost to an organism (Parry 1983, Kiørboe et al 1985, Clarke 1993). Hence, several authors have argued that seasonal changes in the respiration rate of poikilotherms could be mainly a reflection of the effect of temperature on growth and reproduction rather than a direct effect of temperature on respiration (Parry 1983, Clarke 1993). Poikilotherms may also display species-specific physiological plasticity and genetic adaptation which enable them to cope with seasonal and latitudinal changes in temperature (Pretch 1958, Somero 2012, Dam 2013).

Despite previous studies the relative importance of different environmental factors on copepod respiration remains unclear. Understanding how copepod metabolism varies with ambient conditions is also important for the correct parameterization of ecosystem models (Stock \& Dunne et al. 2010). Some models have proposed simple equations to describe the metabolic rate of all organisms from "first principles", using a combination of body mass scaling and thermodynamics laws (Gillooly et al. 2001, Enquist et al. 2003, Brown et al. 2004). These predictive models generally use fixed body mass scaling such as $b=0.75$ and metabolic thermal coefficient values such as the activation energy $\mathrm{Ea}=0.63 \mathrm{eV}$ derived from the Arrhenius formulation. Similarly other modelling studies commonly use empirically derived values of the thermal coefficient $\mathrm{Q}_{10}$ between 2 and 4 (e.g. Olonscheck et al. 2013). However, these Ea and $\mathrm{Q}_{10}$ values are typically derived from acutely measured metabolism-temperature 
rates (i.e. M-T curves) of animals maintained under optimal feeding conditions (Peters 1986). In nature, however, copepod can often be food limited (Hirst \& Bunker 2003) and under such circumstances respiration rate is reduced and does not respond to temperature changes in the same way of that of well fed organisms (Mayzaud 1976, Thor 2003). Hence, Cossins \& Bowler (1987) have argued that eco-physiological studies should measure acclimatised metabolic rates as these are ecologically meaningful. Acclimatised rates refer to the physiological rates of poikilotherms measured at in situ conditions. In contrast acclimated rates refers to the rates of poikilotherms maintained in the laboratory at a given temperature whereas "acute" rates refers to measurements made on poikilotherms maintained in the laboratory and exposed to a sudden change in ambient conditions i.e. generally temperature (Cossins \& Bowler 1987)

Overall, published data on respiration rates of copepod acclimatised to in situ conditions are very scarce. One of the reason for such scarcity is that the method adopted by previous investigators to measure seasonal changes in respiration rate have been often inadequate; for instance, most studies have disregarded the effect of the nutritional condition and acute temperature exposure on metabolism by measuring copepod maintained under different feeding conditions at fixed arbitrary temperatures (Berner 1962, Conover 1962, Marshall \& Orr 1966, Gaudy 1973, Gaudy \& Thibault-Botha 2007). Thus, differences in methodological approaches used in the literature to measure copepod respiration rate make comparisons and synthesis of published data difficult and their use in predictive ecological models unreliable.

The small copepod Temora longicornis often dominates the spring and early summer zooplankton communities of coastal temperate waters of the North Atlantic (Peterson 1985, Fransz et al. 1991, Castellani \& Lucas 2003). In its environment this species experiences a wide fluctuation in temperature and feeding conditions over the seasonal cycle (Castellani \& Altunbaş 2006). Because of its reduced ability to store body lipid, T. longicornis closely depends on its food supply to meet basal energy requirements let alone to grow and reproduce (Clarke \& Walsh 1993, Kreibich et al. 2008). Such physiological trait makes this species an ideal model organism to study how environmental change affects the respiration rate of small neritic copepods. Hence, the aim of this study was to investigate how the acclimatised respiration rate of adult copepod $T$. longicornis varies in relation to seasonal changes in body mass, temperature, salinity, prey availability and reproduction. In addition, we explore whether temperature acclimatised respiration rates differ from acclimated and acutely measured rate of copepod maintained in the laboratory under high food concentration. 


\section{Material and methods}

\section{Sampling}

Zooplankton was collected weekly, between April 1996 and April 1997, with a 200 $\mu \mathrm{m}$ mesh WP-2 plankton net fitted with a non-filtering cod-end from the St. George Pier, Menai Strait (53 $\left.13^{\prime} \mathrm{N}, 4^{\circ} 09^{\prime} \mathrm{W}\right)$, eastern Irish Sea. After collection, the plankton was immediately re-suspended into an opalescent, polypropylene aspirator containing $20 \mathrm{~L}$ of natural seawater pre-screened through a $200 \mu \mathrm{m}$ mesh filter to exclude predators. Salinity (S, ppt) and temperature $\left(\mathrm{T},{ }^{\circ} \mathrm{C}\right)$ were measured with a CTD (Braystoke, Series 600) at $2 \mathrm{~m}$ intervals from the surface to the seabed (i.e maximum of $20 \mathrm{~m}$ water depth) during each sampling. Water samples for chlorophyll-a concentration $\left(\mathrm{Chl}, \mu \mathrm{gl}^{-1}\right)$ and microplankton community characterisation were collected with a $2 \mathrm{~L}$ Niskin bottle at $\sim 2 \mathrm{~m}$ depth from the surface. Chl was determined from water samples of $100 \mathrm{ml}-750 \mathrm{ml}$, filtered onto $\mathrm{GF} / \mathrm{F}$ filters, extracted in neutralised $90 \%$ acetone solution for $24 \mathrm{hrs}$ at $4{ }^{\circ} \mathrm{C}$ in the dark and measured using a Turner 10 fluorometer (Tett 1987). Microplankton samples were immediately fixed with Lugol's Iodine to $2 \%$ final concentration (Nielsen \& Kiørboe 1994) stored into $100 \mathrm{ml}$ dark glass bottles in the dark at $4^{\circ} \mathrm{C}$ and analysed by the Utermöhl (1958) technique within one month.

\section{Copepod maintenance prior to respiration rate experiments}

Adults T. longicornis were sorted from the catch within one hour of collection in a walkin cold room set at in situ temperatures between $5^{\circ} \mathrm{C}$ and $17.5^{\circ} \mathrm{C}$. The copepods were used for one of the three following experiments: to investigate 1) seasonal changes in acclimatised respiration rate, 2) the respiration rate of copepod acclimated to temperature in the laboratory and 3) the respiration rate of copepods exposed to a sudden (i.e. acute) temperature change. Here we refer to "acclimatised" rates for the respiration rates of copepods measured at in situ conditions, to "acclimated" rates for measurements on copepods maintained in the laboratory at a temperature different from in situ and to "acute" rates for measurements made on copepods maintained in the laboratory and exposed to a sudden temperature change (Cossins \& Bowler 1987). Thus, copepods were maintained under different conditions according to the type of experiment performed. The $T$. longicornis measured for 1) the seasonal respiration rate experiment were kept in batches of up to 10 individuals $\mathrm{L}^{-1}$ in $5 \mathrm{~L}$ glass jars filled with natural seawater pre-screened through a $250 \mu \mathrm{m}$ mesh sieve and in temperature controlled water 
baths for a maximum of 1 day at their original in situ temperature. The respiration rates of copepod 2) acclimated and 3) acutely exposed were measured over the temperature range of $4^{\circ} \mathrm{C}-20^{\circ} \mathrm{C}$ and these copepods were maintained in the laboratory on ad libitum diet of the cultured flagellate alga Rhinomonas reticulata (Novarino 1991) for a week before measurements. The water in the jars was changed every other day by sieving the copepods in a submerged $200 \mu \mathrm{m}$ sieve to avoid damage to the animals and gently re-suspended with some remaining water in a cleaned jar containing UV-treated filtered to $0.2 \mu \mathrm{m}$ seawater (UFSW) and fresh cultured micro-algae. Jars were cleaned overnight with a $1 \%$ solution of sodium hypochlorite and thoroughly rinsed with hot tap water to remove chemical residues. We also carried out a preliminary experiment to assess the time required by freshly caught copepods to attain a stable routine respiration rate once deprived of food to avoid the effect of the increase in oxygen consumption resulting from "stress" after capture (Marshall \& Orr 1966) and from feeding metabolism (viz. Specific Dynamic Action, SDA, Kiørboe et al. 1985, Secor 2009). Thus, freshly caught copepods were placed in filtered seawater and their respiration rate measured continuously until respiration rate stabilised. An inverse function fitted to the data set obtained from this time course experiment indicated that copepod respiration rate reached a stable routine rate approximately 10 hours after capture and that such respiration rate remained stable at $\sim 1.7 \mathrm{nl} \mu \mathrm{g} \mathrm{DW}^{-1} \mathrm{hr}^{-1}$ over at least the following 24 hours (Figure 1). Hence, a minimum time of 10 hours since the start of fasting was allowed to elapse prior to all respiration rate measurements carried out in the three experiments outlined above.

\section{Respiration rate measurements}

\section{Seasonal variation in copepod respiration rate in the field}

We measure the seasonal variation in the respiration rate of adult $T$. longicornis between April 1996 and April 1997. Here respiration rate corresponds to routine rate, that is, the oxygen consumed over time by fasting copepod at minimum uncontrolled motor activity (Ikeda et al. 2001). The respiration rate of fasting copepods was measured individually using a polarographic oxygen electrode $\left(\mathrm{pO}_{2}\right.$-electrode, Strathkelvin model 1302) sensitive to changes in oxygen tension in a fluid media (Kanwisher 1959). The $\mathrm{pO}_{2}$-electrode was fitted to the base of a closed transparent glass micro-respirometer chamber of $100 \mu \mathrm{l}$ to $150 \mu \mathrm{l}$ in volume to allow regular monitoring of animal activity and behaviour. The temperature inside the respirometer was kept constant within $\pm 0.2{ }^{\circ} \mathrm{C}$ by a thermostat through a re-circulating water bath system allowing a continuous water flow in the chamber water jacket. The $\mathrm{pO}_{2}$-electrode was connected 
to an $\mathrm{O}_{2}$-meter (Strathkelvin inst. model 781) to display the change in oxygen tension inside the respirometer and through this to a chart recorder to obtain a graphical plot of the respiratory activity of the copepods over the time of observation. The $\mathrm{pO}_{2}$-electrode was regularly calibrated with distilled water containing sodium dithionite to set the zero point on the $\mathrm{O}_{2}$-meter, and then with air saturated UFSW to set the $100 \%$ air saturation level. The electrode response was linear over the range $0-100 \%$ air saturation; hence, the amount of oxygen present in the chamber was calculated with the algorithm of Green \& Carrit (1967). The 1302 microcathode oxygen electrode is a high precision electrode with a very small oxygen consumption rate (i.e. $0.5-3 \mathrm{x}$ $\left.10^{-10} \mathrm{mg} \mathrm{O}_{2} \mathrm{~min}^{-1}\right)$. We used a low permeability polypropylene membrane so most of the resulting oxygen gradient is confined to the distance between the outside of the membrane and the cathode surface. Consequently there is no need for vigorous physical movement of the solution to replenish the oxygen at the outer surface of the membrane. However, correction for electrode oxygen consumption was performed at regular intervals by running an oxygen respiration measurement without the animal (i.e. the blank). The blank was then subtracted from the oxygen rate measurement of the copepod. Copepods were measured under dim light conditions since bright light has been shown to increase the respiration rate in some species (Marshall et al 1935). Respiration measurements were run for 1 hour maximum.

\section{Copepod dry weight vs length relationship}

At the end of each experiment, the prosome length of copepod was measured with an eye-piece graticule under a dissecting microscope (Wild M5). Lengths were converted to body mass from the regression $\ln \mathrm{DW}=2.79 \ln \mathrm{PL}-15.9(\mathrm{r}=0.92, \mathrm{p}<0.001$, d.f. $=29)$, constructed using copepod from the present study and published by Castellani \& Altunbaş (2006), where PL is prosome length in $\mu \mathrm{m}$ and DW is the dry weight in $\mu \mathrm{g}$. The relationship was obtained by measuring 30 groups of adult copepods consisting of between 20-30 individuals of similar prosome length $( \pm 20 \mu \mathrm{m})$ over the full size range. The copepods were dried in preweighed aluminium cups in an oven at $50{ }^{\circ} \mathrm{C}$ until the weight stabilised and they were weighed to the nearest $1 \mu \mathrm{g}$ with a microbalance (Cahan). Copepod DW was converted to carbon assuming a specific-C content of $40 \%$ (Omori and Ikeda 1984).

\section{Copepod egg production rate}

Measurements of egg production rates (EPR) of T. longicornis were carried out at in situ conditions concomitantly to respiration rate measurements as described by Castellani \& 
Altunbas (2006). Briefly, between 25 and 30 intact active female T. longicornis randomly selected from the catch were incubated individually in 250 crystallising dishes filled with natural sea water pre-screened through a $53 \mu \mathrm{m}$ mesh. The dishes were kept for $24 \mathrm{hrs}$ in a temperature-controlled water bath at the ambient surface temperature $\pm 0.2^{\circ} \mathrm{C}$ (i.e. $1 \mathrm{~m} \mathrm{depth}$ ), under artificial lighting, with an ambient light/dark regime. After incubation, the females were gently removed from the crystallising dishes with a pipette, the content of each dish was filtered through a $53 \mu \mathrm{m}$ sieve, and the eggs and nauplii retained, stained with Lugol's iodine and counted in a Bogorov's tray under a dissecting microscope (Wild M5). The egg counts of copepods found dead or moribund at the end of the incubation time were discarded. EPR was calculated as the total number of eggs produced per female over 24 hours incubation period.

\section{Calculation of the thermal coefficients $Q_{10}$ and activation energy (Ea)}

The relationship between the seasonal changes respiration rate of $T$. longicornis with temperature was investigated determining the thermal coefficient $\mathrm{Q}_{10}$ which is commonly used to describe the increase in physiological rates over a $10{ }^{\circ} \mathrm{C}$ change ( Schmidt-Nielsen 1990) (Eq. $1)$ :

$$
\mathrm{Q}_{10}=\left(\frac{\mathrm{K}_{1}}{\mathrm{~K}_{2}}\right)^{\frac{10}{\left(\mathrm{t}_{1}-\mathrm{t}_{2}\right)}}
$$

where $K_{1}$ and $K_{2}$ are the respiration rates at the temperatures $t_{1}$ and $t_{2}$ respectively.

We also investigated the dependence of respiration on temperature using the Arrhenius equation (Eq. 2) by plotting the reciprocal of the temperature, expressed in degrees Kelvin $(\mathrm{K})$ against the respiration rates:

where $\mathrm{k}$ is the reaction velocity constant, $\mathrm{A}$ is the frequency factor constant, e is the natural base of the logarithms (i.e. 2.718.. ), $\mathrm{T}$ is the absolute temperature in $\mathrm{K}, \mathrm{R}$ is the gas constant (i.e. $8.31 \mathrm{~J} \mathrm{~mole}^{-1} \mathrm{~K}^{-1}$ ) and $\mathrm{Ea}$ (i.e. in $\mathrm{J} \mathrm{mol}^{-1}$ ) is the activation energy. The change in reaction velocity with temperature can be predicted from the proportionality constant Ea of an integrated form of the Arrhenius equation, that is:

$$
k=A e^{-\frac{E a}{R T}}
$$




$$
\ln \left(\frac{\mathrm{k}_{2}}{\mathrm{k}_{1}}\right)=\frac{\mathrm{Ea}}{\mathrm{R}\left(\frac{1}{\mathrm{~T}_{1}}-\frac{1}{\mathrm{~T}_{2}}\right)}
$$

264

where $k_{1}$ and $k_{2}$ are the reaction velocities constant at temperatures $T_{1}$ and $T_{2}$ in $K$. The Arrhenius plot of $\ln \mathrm{k}$ against the reciprocal of the absolute temperature gives a straight line of slope equal to $\mathrm{Ea} / \mathrm{R}$ from which $\mathrm{Ea}$, the activation energy, can be calculated as shown in Eq. 4:

$$
\mathrm{Ea}=\text { slope } * 8.31\left(\mathrm{~J} \mathrm{~mol}^{-1}\right)
$$

\section{RESULTS}

\section{Environmental conditions and microplankton composition}

The sampling area is characterised by shallow water depth between $1 \mathrm{~m}$ and $20 \mathrm{~m}$, strong tidal currents and high tidal ranges between $3.4 \mathrm{~m}$ and $6.6 \mathrm{~m}$ resulting in a well mixed water column throughout the year. Table 1 and Figure 2 summarises the seasonal changes in ambient variables at the sampling site already reported by Castellani \& Altunbaş (2006). Briefly, in situ temperature $\left(\mathrm{T},{ }^{\circ} \mathrm{C}\right)$ recorded during the present study varied from a minimum of $5^{\circ} \mathrm{C}$ in February to a maximum of $17.5^{\circ} \mathrm{C}$ in August (Figure 2, a). Salinity changed little reaching maxima values of $34.1 \mathrm{ppt}$ in summer and minima of $31.7 \mathrm{ppt}$ in autumn (Table 1), during the highest local annual rainfall (i.e. 110-126 mm month ${ }^{-1}$, Royal Meteorological Society, Weather Log 1996-1997).

The early spring increase of $\mathrm{Chl}$ from low winter concentration of $0.5-0.9 \mu \mathrm{g} \mathrm{l^{-1 }}$ to $3-8 \mu \mathrm{g} \mathrm{l}^{-1}$ (Figure 2, b) was almost exclusively diatomaceous and included species like Ditylum brightwelli, Skeletonema costatum, Chaetoceros sp., Asterionella sp. and Thalassiosira sp. Between April and June the microplankton community was replaced by the mixed diatom-flagellates bloom of Phaeocystis sp.-Rhizosolenia delicatula during which Chl increased to $\sim 16-26 \mu \mathrm{g} 1^{-1}$. The spring bloom was followed by euglenoids and cryptomonaslike flagellates. A series of monospecific diatom blooms of Leptocylindrus danicus, Rhizosolenia styliformis and Guinardia flaccida developed in summer and autumn, with Chl ranging between $\sim 3 \mu \mathrm{g} 1^{-1}$ to $8 \mu \mathrm{g} \mathrm{l}^{-1}$. Ciliate biomass, mostly belonging to the genus Strombidium, also peaked between spring early-summer and it was correlated with Chl concentration $(\mathrm{r}=0.67, \mathrm{p}<0.05$, d.f. $=33)$. Dinoflagellates, on the other hand, peaked in summer after the Chl maxima (Castellani \& Altunbaş 2006). 


\section{Seasonal variation of copepod respiration with biotic and abiotic variables}

T. longicornis respiration rates began to increase between January and April, reached a maximum in August $\left(\mathrm{R}\right.$, mean $\left.\pm \mathrm{SE}, 83.2 \pm 7.6 \mathrm{nlO}_{2} \operatorname{cop}^{-1} \mathrm{hr}^{-1}\right)$ and a lower secondary peak in October-November before it declined to the annual minimum in December $(\mathrm{R}$, mean $\pm \mathrm{SE}$, $40.4 \pm 5.7 \mathrm{nlO}_{2} \operatorname{cop}^{-1} \mathrm{hr}^{-1}$ ) (Figure 2, c). In contrast copepod dry weight (DW, mean $\pm \mathrm{SE}$ ) ranged between 19.6 $\pm 1.1 \mu \mathrm{g}$ in September and $42.9 \pm 3.7 \mu \mathrm{g}$ in February (Figure 2, c \& d). The seasonal change in egg production rate (EPR) at the study site has already been reported in detail by Castellani \& Altunbaş (2006). Briefly T. longicornis produced eggs all year round. A mean $( \pm \mathrm{SE})$ EPR maximum of $48 \pm 7$ egg female $\mathrm{e}^{-1} \mathrm{~d}^{-1}$ occurred in spring-early

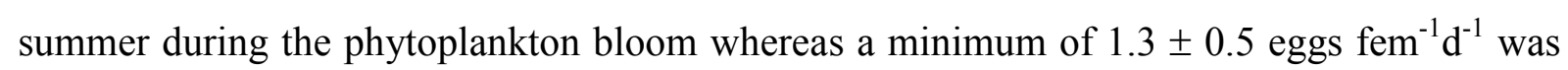
recorded in autumn-winter (Figure 2,e). In situ copepod respiration rate followed the variation in DW, Chl, EPR and T (Figure 2). Logarithmically transformed respiration rate (ln R) was significantly correlated with $\ln \mathrm{DW}(\mathrm{r}=0.44 ; \mathrm{df}=297 ; \mathrm{p}<0.001)$, $\ln \mathrm{Chl}(\mathrm{r}=0.33$; df = 297; $\mathrm{p}<0.001)$, ln EPR $(\mathrm{r}=0.33 ; \mathrm{df}=186 ; \mathrm{p}<0.001)$, $\mathrm{T}(\mathrm{r}=0.23 ; \mathrm{df}=297 ; \mathrm{p}<0.001)$ and salinity $(r=0.19 ; \mathrm{df}=297 ; \mathrm{p}<0.001)$. Table 2 shows the results of the multiple regression analysis between $\ln \mathrm{R}$ and $\ln \mathrm{DW}, \mathrm{T}, \ln \mathrm{Chl}$, and $\ln \mathrm{EPR}$ for the temperature intervals $5{ }^{\circ} \mathrm{C}$ to $17.5^{\circ} \mathrm{C}$ and $8{ }^{\circ} \mathrm{C}$ to $13{ }^{\circ} \mathrm{C}$ (i.e. the temperature range within which respiration rate increased linearly with temperature, see Figure 4). The normalised $\beta$-coefficient from the multiple regression analysis, over both temperature intervals, indicated that, $\ln$ DW ( $(=0.6-0.5)$ temperature $(\beta=0.4-0.5)$, ln Chl $(\beta=0.2)$ and $\ln$ EPR $(\beta=0.1)$ whereas salinity was not significant. Table 2 also shows that the goodness of fit of the regression is higher for the $8{ }^{\circ} \mathrm{C}$ to $13{ }^{\circ} \mathrm{C}$ temperature interval where respiration rate increase linearly with temperature.

\section{Relationship between respiration and body dry weight}

Copepod respiration rate increased with DW with the largest copepods showing the widest range in rates (Figure 3). Table 3 summarises the relationship between respiration rate and body DW of $T$. longicornis for different months and in situ temperatures. Following logarithmic transformation, the slopes (i.e. b) of the equations ranged from 0.83 to 1.35 and T-test analysis indicated that they were not significantly different from unity. Comparison of the slopes using ANCOVA ( $G L M, d f=9, F=0.44, p=0.915)$ also showed that they were no significantly different from each other. Overall, the total yearly variation in copepod 
respiration rates with DW was larger than for each individual month and a positive trend in respiration rate with temperature was evident (Figure 3). Statistical analysis using ANCOVA $(\mathrm{df}=9, \mathrm{~F}=25, \mathrm{p}<0.0001)$ confirmed that the intercepts of the regression equations in Table 3 , were significantly different from each other.

\section{Relationship between respiration and in situ temperature}

The variation in mean monthly weight specific respiration rate $\left(\mathrm{R}_{\mathrm{sp}}, \mathrm{nlO}_{2} \mu \mathrm{gDW}^{-1} \mathrm{hr}^{-1}\right)$ with temperature was characterised by a sigmoid pattern (Figure 4); respiration rate remained at its lowest between $5^{\circ} \mathrm{C}$ and $7^{\circ} \mathrm{C}$ from December to April, it increased between $8^{\circ} \mathrm{C}$ and $13^{\circ} \mathrm{C}$ from April to May and reached a maximum plateau between $15^{\circ} \mathrm{C}$ to $17.5^{\circ} \mathrm{C}$ from June to August. The pattern of respiration rate with temperature did not change for different DW suggesting that the sigmoid trend was not caused by seasonal variation in copepod body mass. A logistic function model was fitted to the data set as such model was found to fit statistically (i.e. $r^{2}=93 \%$, See Figure 4) better than the linear regression model (i.e. $r^{2}=86 \%$ ). The multiple regression model shown in Table 2 predicts that the highest rate of increase in the acclimatised respiration of $T$. longicornis occurs between $8^{\circ} \mathrm{C}$ and $13^{\circ} \mathrm{C}$ (i.e. $\mathrm{Q}_{10}=2.01-2.88$ ). In contrast, above and below this temperature range respiration rate remains virtually constant (i.e. $\mathrm{Q}_{10}=1$ ). Overall, the change in respiration rate over the whole in situ annual temperature range was characterised by $\mathrm{Q}_{10}$ varying from 1.57 to 1.89 depending on the variables included in the regression model (Table 2a).

Table 2 b) shows the activation energy (i.e. Ea) values calculated from the Arrhenius equation (i.e Eq. 4). Ea varied from $30.5 \mathrm{KJ} \mathrm{mol}^{-1}$ to $42.9 \mathrm{KJ} \mathrm{mol}^{-1}$ (or $0.31 \mathrm{eV}-0.45 \mathrm{eV}$ ) over the whole in situ temperature range reaching the highest values between $47.7 \mathrm{KJ} \mathrm{mol}^{-1}$ to 71.7 $\mathrm{KJ} \mathrm{mol}^{-1}$ (or $0.49 \mathrm{eV}-0.74 \mathrm{eV}$ ) when calculated over the $8{ }^{\circ} \mathrm{C}$ to $13{ }^{\circ} \mathrm{C}$ temperature range.

\section{Relationship between respiration with $\mathrm{Chl}$ and EPR}

Figure 5 and Figure 6 show the pattern of increase in respiration rate (i.e. R) with Chl and EPR. Both relationships were characterised by an asymptotic trend with $\mathrm{R}$ reaching a maximum around $5 \mu \mathrm{g} \mathrm{Chl} \mathrm{L}{ }^{-1}$ and $15 \mathrm{egg} \mathrm{fem}^{-1}$ day $^{-1}$. These results suggest that $\mathrm{R}$ reaches its maximum values during the phytoplankton bloom i.e. when feeding conditions for copepods are most favourable (Figure 2 b). Moreover, the relatively constant $R$ (i.e. energy consumption) for EPR increasing from $\sim 15$ to 50 eggs fem ${ }^{-1} \mathrm{~d}^{-1}$ suggests higher reproduction efficiency possibly linked to higher food quality such as the increase in nitrogen rich ciliate diet during the spring bloom. 


\section{Changes in respiration rate with gender}

Adult males represented about $8 \%$ of the total copepod in the population sampled during the present study and they were smaller than females. As a result the mean weight specific respiration rate of $T$. longicornis males $\left(1.67 \pm 0.12 \mathrm{nlO}_{2} \mu \mathrm{gDW}^{-1} \mathrm{hr}^{-1}\right)$ was on average lower than that of females $\left(2.27 \pm 0.048 \mathrm{nlO}_{2} \mu \mathrm{gDW}^{-1} \mathrm{hr}^{-1}\right)$. However, comparison of copepod of similar DW measured the in situ temperature of $6.5{ }^{\circ} \mathrm{C}$, showed that the respiration rate of male did not differ significantly from that of the female (Table 4).

\section{Discussion}

\section{Seasonal variation of copepod respiration rate}

We investigated the seasonal variation in the respiration rate of $T$. longicornis acclimatised to field conditions, during one year study, by measuring individually 299 adults over the full range of copepod dry weight (DW), egg production rates (EPR), ambient temperature (T), salinity and chlorophyll-a (Chl) as a proxy for prey availability. In our study, T. longicornis respiration increased from a minimum in December to a maximum during May and August (Figure 2). Results from multiple regression analysis showed that seasonal changes in Ln R were significantly related to $\ln \mathrm{DW}, \mathrm{T}, \ln \mathrm{Chl}$ and $\ln$ EPR (Table 1a). A spring increase in the respiration rate of $T$. longicornis has been reported before by Marshall \& Orr (1966) in the Clyde Sea and by Conover (1959) in Southampton waters; whereas Marshall \& Orr (1966) attributed the rise in the respiration rate of T. longicornis mainly to an increase in copepod body size, Conover (1959) argued that copepod metabolic rates may be "geared to the phytoplankton bloom". However, neither of these authors analysed their field data statistically or tested experimentally the factors which might have affected copepod respiration rendering conclusions from their study speculative. Critically, all previous field investigations disregarded the effect of acute temperature exposure on copepod respiration rate by measuring T. longicornis at a fixed arbitrary temperature (Berner 1962, Marshall \& Orr 1966, Raymont 1959, Conover 1959, See Table 5). In addition, these studies were mainly limited to between March and July. Thus, limited data sets and differences in methodology make the interpretation of published data on copepod respiration difficult and their use in predictive models questionable. In this respect, our investigation represents one of the largest and most comprehensive studies ever conducted on the seasonal changes in the respiration rate of a single copepod species acclimatised to in situ conditions. 


\section{The dependence of respiration on body size}

In our study copepod DW explained the largest proportion of variability in copepod respiration rate. This finding is not surprising since body mass is an important determinant of the metabolic rate of an organism (Peters 1986, Schmidt-Nielsen 1991). On the other hand, the weight exponent $b$ of the power function (i.e. the slope of the ln function) between respiration rate and body weight has been reported to vary widely across taxa (Glazier 2006). In our study b varied from 0.83 to 1.34 (Table 2, Table 3 and Figure 3) and it was not significantly different from unity indicating direct proportionality (i.e. isometric scaling) between respiration rate and body mass. Conover (1959) reported a weight exponent of 0.76 for T. longicornis from Southampton waters. Using the data published by Marshall \& Orr (1966), we calculated a weight exponent $( \pm \mathrm{SE})$ of $1.22 \pm 0.23\left(\mathrm{df}=6 ; \mathrm{F}=27.9 ; \mathrm{r}^{2}=81.8 \%\right.$; $\mathrm{p}<0.003$ ) for T. longicornis from the Clyde Sea. Thus, the weight exponent we estimated for T. longicornis in our study is similar to values reported by previous authors for this species and to the range of 0.5 and 1 generally reported for copepod (Mauchline 1998, Ikeda et al. 2000).

Although, it is generally assumed that metabolic rate increases as the body mass to the power of $2 / 3$ (i.e. 0.66 , proportionality to body surface) or $3 / 4$ (i.e. 0.75 , intermediate proportionality between body weight and surface), there is still no broad consensus regarding the value of this coefficient (Kleiber 1961, Brown et al. 2004, Downs et al. 2008, Kolokotrones et al. 2010, Glazier 2010, Agutter \& Tuszynski 2011). West et al. (1997) have argued that the $3 / 4$ metabolic scaling is the result of the fractal geometry of the internal network present in organisms (Fractal Network Theory, FNT), including the circulatory and respiratory systems. However, recent theoretical and empirical research has questioned the $3 / 4-$ power law and the FNT model proposed to explain it, by showing that such model is based on questionable or unsubstantiated assumptions (Glazier $2009 \&$ 2010; Kolotrones et al. 2010; Agutter and Tuszynski 2011). Kolotrones et al. (2010) have shown that the relationship between metabolic rate and body mass has a convex curvature on a logarithmic scale suggesting that the metabolic coefficient is highly sensitive to the body mass range used. Moreover, Agutter \& Tuszynski (2011) advocated that the quantum metabolism (QM) theory which adopt a molecular-cellular perspective can be used to predict the large variations in body scaling exponents and predict the temperature dependence of the proportionality constant, issues that have eluded models such as the FNT. Interestingly isometric scaling of metabolic rate appears to be common in planktonic animals and Glazier (2006 \& 2009) argued that it probably represents an adaptation to the high-energy cost of continual 
swimming to stay afloat, rapid growth rates and reproductive rates in response to high levels of mortality in open water.

\section{The relationship between respiration rate and temperature}

The respiration rate of $T$. longicornis increased with temperature (Figure 4) similar to what generally reported for other poikilotherms (Schmidt-Nielsen 1991, Mauchline 1998, Castellani et al. 2005). Interestingly, respiration rates from our study overlap with rates reported by Berner (1962) and Marshall \& Orr (1966) at $10^{\circ} \mathrm{C}$ and Le Ruyet-Person et al. (1975) at $16-17^{\circ} \mathrm{C}$, but they are lower than rates reported by Raymont (1959) at $15^{\circ} \mathrm{C}$ and by Conover (1959) at $20^{\circ} \mathrm{C}$ for T. longicornis of comparable DW (Figure 7) measured over a similar temperature range (Figure 8). One of the reasons for such discrepancy may be attributed to methodological differences between studies; whereas we measured individually the respiration rate of fasting copepod acclimatised to environmental conditions, previous authors measured groups of copepod, exposed to variable feeding conditions, at a fixed arbitrary temperature (See Table 5). Berner (1962) and Marshall \& Orr (1966) measured the respiration rate of fasting $T$. longicornis at $10^{\circ} \mathrm{C}$ over $40-50 \mathrm{hrs}$ incubation between the end of March and mid-July. Le Ruyet-Person et al. (1975) measured single fasting copepod acclimatised to $16-17{ }^{\circ} \mathrm{C}$ during 3-6 hrs incubation in July. In contrast, Raymont (1959) and Conover (1959) measured copepod, maintained in the laboratory between $5^{\circ} \mathrm{C}$ and $10^{\circ} \mathrm{C}$ on cultured phytoplankton, at $15^{\circ} \mathrm{C}$ and $20^{\circ} \mathrm{C}$ respectively, over $3 \mathrm{hrs}$ experiments between February and June (Table 5). Exposing a poikilotherm to a sudden temperature change, results in a shift in the physiological rate lasting minutes to hours, known as the acute rate (Cossins $\&$ Bowler 1987). This rate, which is used to construct the acutely measured metabolismtemperature curve (i.e. acute M-T curve, Prosser \& Brown 1961) is generally followed by a new, steady or acclimated state, which is gradually acquired some hours to days after the temperature change (Pretch 1958). In T. longicornis a temperature shift between $5^{\circ} \mathrm{C}$ to $15^{\circ} \mathrm{C}$ degrees requires between $\sim 2$ to 6 days, respectively, before respiration stabilises to the new rate, intermediate between the original and the acute rate (Castellani \& Altunbaş, in preparation). Therefore, it is likely that the long incubation times used by Berner (1962) and by Marshall \& Orr (1966) enabled copepod respiration to acclimate to their $10^{\circ} \mathrm{C}$ experimental temperature following a shift of at most $6^{\circ} \mathrm{C}$ i.e. considering in situ temperatures ranging from $4^{\circ} \mathrm{C}$ to $16^{\circ} \mathrm{C}$ for their study area. The copepods measured by Le Ruyet-Person et al. (1975) were also acclimatised and, therefore, their data coincide with our measurements. In 
contrast, the high respiration rates reported by Raymont (1959) and Conover (1959), who measured copepod over a short time (i.e. $3 \mathrm{hrs)} \mathrm{following} \mathrm{temperature} \mathrm{increases} \mathrm{of} \mathrm{up} \mathrm{to}$ $\sim 15^{\circ} \mathrm{C}$, probably corresponded to acute respiration rates (Table 5).

In our study, the respiration rate of $T$. longicornis acclimatised to field temperatures between $5^{\circ} \mathrm{C}$ and $17.5^{\circ} \mathrm{C}$ followed a sigmoid pattern with $\mathrm{Q}_{10}$ ranging between 1 and 2.88 depending on the temperature interval (mean $\mathrm{Q}_{10}$ ranging between 1.56 and 1.88, Table 2 and Figure 4). In contrast, the relationship we obtained from a compilation of published field data for $T$. longicornis was characterised by an exponential increase in respiration between $10^{\circ} \mathrm{C}$ and $20^{\circ} \mathrm{C}$ and by a higher mean $\mathrm{Q}_{10}$ of 3.09 (Figure 8 ). The $\mathrm{Q}_{10}$ reported for the respiration rates of marine copepod usually range between 2 and 4, although values above and below this range have also been reported (Hirche 1987, Mauchline 1998, Gaudy \& Thibault-Botha 2007). It is noteworthy, however, that $\mathrm{Q}_{10}>2$ are generally estimated from acute measurements of copepods maintained in the laboratory on high microplankton concentration (Cossins \& Bowler 1987, Ikeda et al. 2001, Castellani et al. 2005). For instance, using data by Gauld \& Raymont (1953) and our own data (Figure 9-a) on the acute respiration rates of fasting $T$. longicornis maintained on at libitum microalgal diet, we calculated mean $\mathrm{Q}_{10}$ values of 2.4 for the temperature interval $4^{\circ} \mathrm{C}$ to $20^{\circ} \mathrm{C}$. As mentioned above, the acutely measured respiration rate is a transient and short lived shock response of an organism exposed to a sudden and often unrealistic change in temperature (e.g. the $15^{\circ} \mathrm{C}$ temperature shift applied by Raymont 1959 and Conover 1959) and as such it represents a distortion of the "natural" respiration rate. In contrast, the acclimatised respiration rate, we measured in the present study, displays the ecologically meaningful relationship between metabolism and the ambient conditions experienced by an organism (Cossins \& Bowler 1987). Hence, the high $\mathrm{Q}_{10}$ we obtained pooling published field data on $T$. longicornis was probably the result of the acute measurements by Raymont (1959) and Conover (1959).

Respiration is typically measured on fasting copepod (Berner 1962, Marshall \& Orr 1966, Ikeda et al. 2001, this study Table 5) to avoid the added effect of Specific Dynamic Action (i.e. SDA, Kiørboe et al. 1985, Thor 2000, Secor 2009). However, the copepods measured by Raymont (1959) and Conover (1959) were maintained in the laboratory on cultured microalgae and it is unclear whether they had been fasting prior to experiment. Since the respiration rate of $T$. longicornis takes approx. $10 \mathrm{hrs}$ to decrease to the routine rate after copepods are deprived of food (Figure 1), it is possible that the higher respiration rates measured by Raymont (1959) and Conover (1959) were also partly due to the effect of SDA. 
The low $\mathrm{Q}_{10}$ of 1 we measured, in the present study, during winter and late summer shows that over that time of the year copepod metabolism did not change with temperature (Figure 4). Values of $\mathrm{Q}_{10}<2$ have been generally interpreted as the result of homeostasis, resulting from seasonal adjustments in enzymes concentration and type (Somero \& Hochachka 1971) and thought to confer a metabolic advantage to organisms living in a temperature fluctuating environment (Gaudy 1972, Gaudy \& Thibault-Botha 2007). However, Clarke (1993) has argued that attempting to explain seasonal variation in oxygen consumption as a direct response of metabolic rate to temperature is simplistic because respiration represents a cost to an organism i.e. ATP demand for physiological processes such as growth, reproduction and locomotion besides the maintenance of basic bodily functions. Organisms are adapted to minimise energetic costs and, therefore, their cells will not synthesize ATP (i.e. will not increase respiration rate) unless it is required to produce work and unless there is sufficient fuel to do so. Hence, Clarke (1993) has proposed that seasonal changes in the oxygen consumption of poikilotherms could reflect changes in their growth and reproductive rates. Interestingly, we obtained the lowest rate of increase in respiration (i.e. $\mathrm{Q}_{10}=1$ ) during winter and late summer when both prey concentration and copepod reproductive rates were lower (Figure 2, b \& e). In contrast we measured the highest $\mathrm{Q}_{10}$ between 2.01 and 2.88 during spring-early summer at a time when in situ feeding conditions for the copepods were optimal and reproductive activity was maximum (Table 2, Figure $2 \&$ Figure 4). Similarly, Ikeda et al (2001) reported $\mathrm{Q}_{10}$ between 1.8 and 2.1 for the respiration rate of fasting copepod species acclimatised between $-1^{\circ} \mathrm{C}$ and $30^{\circ} \mathrm{C}$ calculated only from measurements made during spring-summer when feeding conditions were most favourable.

A comparison of acclimatised respiration rate, from the present study, with acclimated and acute respiration rate suggests that the response of $T$. longicornis metabolism to temperature depends on both exposure time and nutritional conditions (Figure 9). The respiration of field acclimatised copepod which experience a lower and more variable availability/quality of prey was the most variable (i.e. sigmoid trend) and the mean rate of change the lowest $\left(\mathrm{Q}_{10}=1.56-1.88\right)$. The acclimated respiration of laboratory maintained copepod increased exponentially but the rate of change was intermediate $\left(Q_{10}=2.1\right)$. In acutely measured copepod the response was also exponential but the rate of increase was the highest $\left(\mathrm{Q}_{10}=2.4\right)$. However, Figure 9-a shows a substantial overlap between the three data sets particularly in the middle of the temperature range. The logarithmic transformation did not linearise the sigmoidal pattern of the field acclimatised respiration rates and therefore a statistical comparison between the slopes of the relationships was not possible. Nevertheless, 
we compared the data sets using Two-sample T-test statistic with equal variances at each of the common temperature. Our results show that the respiration rates of field acclimatised copepods was significantly higher at $5^{\circ} \mathrm{C}(\mathrm{df}=40, \mathrm{t}=2.54, \mathrm{p}=0.014)$ and significantly lower at $17.5{ }^{\circ} \mathrm{C}(\mathrm{df}=35, \mathrm{t}=-3.31, \mathrm{p}=0.0021)$ compared to that of acutely measured copepods. Similarly, field acclimatised respiration rates were significantly lower than laboratory acclimated rates at $17.5^{\circ} \mathrm{C}(\mathrm{df}=34, \mathrm{t}=-2.33, \mathrm{p}=0.025)$, but at $5^{\circ} \mathrm{C}$ they were significantly higher than acclimated rates only at $10 \%(\mathrm{df}=37, \mathrm{t}=1.48, \mathrm{p}=0.0734)$. There were no significant differences between the respiration rates of acute and laboratory acclimated rates. The higher respiration rates we measured for acclimatised copepods at $5^{\circ} \mathrm{C}$ may be the result of not only acclimatisation but also of the favourable feeding conditions encountered by the copepods in the field at the beginning of February and the associated high reproductive rates; at this time $\mathrm{Chl}$ concentration had already increased above winter level to reach $\sim 1 \mu \mathrm{g} \mathrm{L}{ }^{-1}$ due to a mixed diatom bloom and this promoted an increase in copepod EPR (mean $\pm \mathrm{SE}, 16 \pm$ 9.1 eggs fem ${ }^{-1}$ day $^{-1}$; range $0-61$ eggs fem $^{-1}$ day $^{-1}$ ). Diatoms are known to support higher egg production rates in T. longicornis compared to other phytoplankton diets (Dam and Lopes 2003, Jonasdottir et al 2009) including the flagellate diets we fed to the copepods in our acclimated and acute respiration rates experiments. Similarly the lower respiration rates we measured for the copepods from the field at $17.5^{\circ} \mathrm{C}$ may be the result of poorer feeding conditions (i.e. Noctiluca spp. bloom and the absence of diatoms) in the field compared to copepod maintained on a high flagellate diet in the laboratory and associated lower reproductive rates (see also next section). In support of our argument, Figure 10 shows a sigmoid trend in the weight specific reproduction rate of $T$. longicornis (measured during the same study and published in Castellani and Altunbas 2006) with temperature which is very similar to the acclimatised respiration rate trend presented in Figure 4 and Figure 9-a. Furthermore, the logistic equation we fitted to the acclimatised respiration rate data in Figure 4 and Figure 9-a is very often used to describe the growth of organisms and hence our results suggest that the seasonal trend in in situ respiration rate we measured largely reflects female copepod growth rate i.e. their reproductive rate (Figure 10). In summary, our findings suggest that respiration rates measurements carried out under acute temperature exposure are not representative of field acclimatised copepod respiration rates particularly at the extreme of the temperature range and depending on the nutritional conditions of the copepods. It is worth noting, however, that our findings may not apply to copepods species which store large body 
lipid reserves or those who experience large temperature changes over a short time scale through, for instance, diel vertical migration.

\section{The effect of food sources and reproduction on respiration}

The positive significant relationship we found between $T$. longicornis respiration rates and ambient $\mathrm{Chl}$ suggests that seasonal changes in nutritional conditions were an important determinant of copepod metabolic rates (Table 2). Our results support the observation made by Conover (1959) that the spring increase in the respiration rate of $T$. longicornis might "be geared in some way to its food supply". Similarly, other studies have reported higher respiration rates for Calanus finmarchicus, Calanus helgolandicus and Calanus hyperboreus during the phytoplankton bloom in spring and summer compared to rates in winter (Marshall \& Orr 1958, Conover \& Corner 1968, Butler et al. 1970).

Aerobic metabolism is tightly coupled with feeding particularly in small copepods such as T. longicornis that do not store large lipid reserves (Clarke \& Walsh 1993, Kreibich et al. 2008). For instance, citrate synthase, which is an important metabolic key enzyme of the Tricarboxylic Acid Cycle, decreases already after $24 \mathrm{~h}$ in starving T. longicornis (Clarke \& Walsh 1993). The increase in respiration rate of fed copepod, i.e. SDA, is largely related to protein biosynthesis (i.e. to growth and reproduction) and protein metabolism, rather than to the mechanical filtering and ingestion of the food (Kiørboe et al. 1985, Thor 2000, Clarke \& Fraser 2004, Secor 2009). However, protein synthesis is also a key component of basal metabolic rate (e.g. protein turnover, Clarke \& Fraser 2004). Basal metabolic rate represents, in fact, the continuous cost the organism must meet to repair cell damage (e.g. protein turnover) and protein recycling (e.g. enzymes). However, the recycling of enzymes is probably not constant and it is associated with the rate of growth which depends on the type and quantity of substrate metabolised (Flynn 2005, Hochachka \& Somero 2002). Thus, the "basal rate" of a fasting poikilotherm can be expected to change according to the growth rate of the organism. The respiration rate of a starved copepod will also depend on the level and type of substrate metabolised (i.e. either protein or lipids) and its body reserves. The copepods we collected in the field were feeding on different concentrations and quality of food sources i.e. either lower or higher compared to the monospecific algal diet we fed to the copepods maintained in the laboratory. Since both the acclimatised and acclimated copepod in our study were fasted for the same length of time prior to measurement, the higher respiration rates we recorded in acclimated copepods at $17.5{ }^{\circ} \mathrm{C}$ compared to those acclimatised in the field 
appears to be the result of a higher level of protein turnover and/or anabolism supported by the constant high prey supply in the laboratory (Figure 9).

In our study, the seasonal change in $T$. longicornis respiration rate was also significantly related to EPR. Coupling between egg production and respiration rate has been reported in A. tonsa (Kiørboe et al. 1985, Thor 2003) and Conover (1962) observed that ripe C. hyperboreus females had higher respiratory rate than immature or spent ones. In adult female copepod anabolic processes are mainly linked to the cost of reproduction (e.g. in the copepod Acartia tonsa, Kiørboe et al. 1985). Several authors have also suggested that body size, food availability and temperature often indirectly influence metabolic rates through their effects on growth rates, rather than directly (Parry 1983, see Clarke 1993 for a critical review of this topic). For instance, Parry (1983) showed that the "cost of growth" could account for up to $80 \%$ of ectotherm metabolism and he interpreted seasonal changes in respiration rates of marine poikilotherms as a reflection of changes in synthetic activity rather than simply the result of a mechanistic response of metabolism to temperature changes. Indeed the protein content (hence the synthetic activity) of $T$. longicornis fluctuates over the year as a result of changes in the nutritional conditions experienced by the copepods (Helland et al. 2003). In our study, however, EPR explained the lowest proportion of variability in respiration compared to other variables. Such result is not surprising since copepod respiration combines different energetic costs besides that of producing eggs. It is also difficult to equate rapid changes in EPR with metabolism because of the lag time between the formation (i.e. demand for ATP) and the release of egg (Tester \& Turner 1990). In addition, in our study we measured respiration on fasting copepods and EPR on copepod that had been feeding before incubation (see material and methods). Furthermore, the asymptotic relationship, shown in Figure 6, between respiration and EPR indicates an increase in reproductive efficiency in spring that might have resulted from an increase in food quality (e.g. the increase in nitrogen rich ciliate during the spring bloom). Results of a recent laboratory study (Nobili et al. in preparation) showing a decrease in the reproductive cost of $T$. longicornis with increase in the $\mathrm{N}: \mathrm{P}$ ratio of the diet would support our field observation. The similarity in the pattern of EPR and respiration rate with temperature we shown in Figure 4 and Figure 10 we already discussed in the previous section also support our view that seasonal changes in metabolic rates were driven by seasonal changes in copepod growth rates. Overall, our results suggest that reproductive activity (i.e. anabolic processes) modulated by food availability and possibly quality also contributed to the observed seasonal changes in the respiration rate of $T$. longicornis. 


\section{Metabolic coefficients and the importance of acclimatised rates for predictive models}

Using the correct metabolic coefficient values is critical to estimate energy flow and secondary production. Our study has shown that the body mass exponent of $T$. longicornis scaled isometrically (i.e. $\mathrm{b}=1$ ) with metabolism similarly to what commonly reported in planktonic animals (Glazier 2006). Such value is significantly different from the coefficient b $=3 / 4$ predicted by the Metabolic Theory of Ecology (MTE, Gilloly et al. 2001, Brown et al. 2004). Our and past studies have also shown that under natural conditions the $\mathrm{Q}_{10}$ of copepod physiological rates are often characterised by $\mathrm{Q}_{10}$ values $<2$ (Present study, Ikeda 1985, Ikeda et al. 2000, Hirst and Bunker 2003). In contrast, the physiological responses to temperature of zooplankton experiencing optimal feeding conditions either in the field or in the laboratory and measured over unrealistic and sudden temperature changes seem to be characterised by $\mathrm{Q}_{10}>2$ (i.e. acute measurements, present study, Peters 1986, Cossins \& Bowler 1987, Hirche 1987). Moreover, our study has also shown that under acclimatised and acclimated conditions the physiology of copepods is characterised by lower $\mathrm{Q}_{10}$ than in copepods exposed acutely to temperature changes. It is not unreasonable to assume that in the marine environment the metabolism of most copepods will have sufficient time to acclimatise to changes in ambient temperature since here seasonal thermal fluctuations are relatively small, compared to the terrestrial environment, due to the higher heat capacity of seawater. Most copepod species experience food scarcity and variable prey quality over large part of the year all of which could affect their metabolism and reproductive rates. In this respect, our results have shown that the goodness of fit of the regression improved when we included Chl and EPR in addition to DW and temperature (Table 2). Moreover, the value of the $\mathrm{Q}_{10}$ differed substantially depending not only on the temperature interval considered but also on the variables included in the regression analysis, whereas the body mass exponent was never significantly different from unity. Modelling studies generally use relatively high values of $\mathrm{Q}_{10}$ to estimate the effect of temperature change on metabolic rates of zooplankton; Interestingly Stock \& Dunne (2010) have observed that the report of high $\mathrm{Q}_{10}$ values by several high profile zooplankton studies (e.g. Huntley \& Lopez (1992) report a $Q_{10}$ of 3 for copepod generation times and Rose \& Caron (2007) report $\mathrm{Q}_{10}$ of 2.4 and 3.75 for bacterivorous and herbivorous protists respectively), has prompted many modelers to adopt a $\mathrm{Q}_{10}$ of 3 despite substantial observational evidence that zooplankton rates (including growth) exhibit $\mathrm{Q}_{10}$ values of 2 or below (Hirst and Bunker 2003, Ikeda 1985, Ikeda et al. 2000). The activation energy (Ea) we calculated from the slopes of the Arrhenius equation for copepod acclimatised between $5{ }^{\circ} \mathrm{C}$ and $17.5^{\circ} \mathrm{C}$ ranged between 31 to $43 \mathrm{KJ} \mathrm{mol}^{-1}$ or 0.31 to $0.45 \mathrm{eV}$ (i.e. $1 \mathrm{eV}=96.49 \mathrm{~kJ} \mathrm{~mol}^{-1}$ ) 
(Figure 9-b \& Table 2b). These values are well below the Ea range 0.60-0.70 eV and the mean Ea values between of $0.63 \mathrm{eV}$ (excluding endotherms) predicted by the MTE (Brown et al. 2004). We recorded the highest $\mathrm{Ea}=0.61 \mathrm{eV}$ only in the temperature interval $8^{\circ} \mathrm{C}-13^{\circ} \mathrm{C}$, that is during the phytoplankton bloom when copepods were exposed to good feeding conditions and actively reproducing (see section above "the relationship between respiration rate and temperature"). Thus, our results indicate that during the largest part of the year the respiration rate of $T$. longicornis would be well below the rates predicted by the MTE equation. This result has important implications for the interpretation of the response of plankton to environmental change and for predictive ecological modelling. In summary, the relationships between physiological rates and ecologically-relevant parameters such as temperature and body size, upon which global predictive models rely, are incomplete and subject to significant methodological artefacts. Additional detailed studies of acclimatised in situ rates as a function of not only temperature and body size but also of other key parameters such as the nutritional conditions, reproductive and growth rates and the genetic "make-up" of the organism are essential to improving these relationships and reducing uncertainties in predicted ecosystem responses to environmental change.

\section{How much carbon is required by $T$. longicornis to support routine metabolism?}

Our results provide information about individual variability of $T$. longicornis respiratory response and energy demand. Metabolic studies based on the O:N ratio have indicated that the main substrate catabolized in small calanoid copepods, such as T. longicornis, is protein (Ikeda 1974, Bamstedt 1988, Thor 2000) because these species usually do not store lipids and carbohydrates in large quantities (Evjemo \& Olsen 1997, Helland et al. 2003). Thus, considering a respiratory quotient $\mathrm{RQ}=0.8$ for protein catabolism (Schmidt-Nielsen 1996) and that $\mu \mathrm{g}$ carbon catabolized $=0.8 \times \mu \mathrm{O}_{2}$ day $^{-1}$ respired $\times 12 \mu \mathrm{g} \mathrm{C} \mu \mathrm{mol}^{-1} / 22.4 \mu \mathrm{l} \mu \mathrm{mol}^{-1}$, the daily carbon requirement by a $T$. longicornis of $1000 \mu \mathrm{m}$ in length, estimated from our multiple regression model (Table 2), would vary from $\sim 5 \%$ and $10 \%$ of body carbon at $5^{\circ} \mathrm{C}$ and $17^{\circ} \mathrm{C}$ respectively. However, Table 2 also shows that using DW and T only, results in copepod C consumption being almost 3 times higher than that estimated taking into account $\mathrm{Chl}$ and EPR. The discrepancy in energetic cost is stronger during the most productive time of the year when copepods are actively reproducing (Table2). 


\section{Summary \& Conclusions}

Using one of the most comprehensive data sets on acclimatised copepod respiration rate, our study has shown that in situ seasonal changes in $T$. longicornis metabolism are the result not only of body mass and temperature but also of copepod nutritional and reproductive conditions. Thus, the constancy of metabolic rate with temperature increase we observed in winter and late-summer appears to be the result of reduced anabolic processes due to food limitation rather than simply a seasonal physiological adjustment to temperature i.e. homeostasis. The lower values of $\mathrm{Q}_{10}$ and Ea we measured in our studies compared to those reported in the literature also suggests that metabolic rates of acclimatised copepods may be less responsive to temperature changes than it has been inferred so far from thermal coefficients calculated from acutely measured rates of copepods maintained in the laboratory on high food ration. The value of the thermal coefficient also differed according to the type of variable used in the regression model. Therefore, using high and fixed coefficients values may lead to overestimate or misrepresentation of copepod respiration particularly under ambient conditions limiting growth and reproduction. Our results have important implications for ecological models aiming to predict energy flow in marine food-webs and to determine the impact of climate change on copepod metabolic rates.

Acknowledgements: The present study was undertaken as part of the requirement of fulfilment of the $\mathrm{PhD}$ degree of $\mathrm{C}$. Castellani and represents a contribution to the NERC thematic project Plankton Reactivity in the Marine Environment (PRIME). We thank P. LeB Williams and A. B. Yule for stimulating the preparation of this work and for providing laboratory facilities. The preparation of this paper was partly funded by the European Commission FP7 EURO-BASIN (European Basin-Scale Analysis, Synthesis, and Integration; Grant Agreement 264 933).

\section{REFERENCES}

Agutter PS and Tuszynski JA (2011) Analytic theories of allometric scaling. Journal of Experimental Biology 214: 1055-1062Bamstedt U (1988) Ecological significance of individual variability in copepod bioenergetics, Hydrobiologia, 167/168:43-59

Berner A (1962) Feeding and respiration in the copepod Temora longicornis (Muller) J Mar Biol Ass UK, 42:625-640

Brown JH, Gilloly JF, Allen AP, Savage VM, West GB (2004) Towards a metabolic theory of ecology. Ecology 85:1771-1789 
Butler EI, Corner EDS, Marshall SM (1970) On the nutrition and metabolism of zooplankton. VIII. Seasonal survey of nitrogen and phosphorus excretion by Calanus in the Clyde Sea area. JMBA UK 50: 525-560

Castellani C, Lucas IAN (2003) Seasonal variation in egg morphology and hatching success in the calanoid copepods Temora longicornis, Acartia clausi and Centropages hamatus. J Plank Res 25: 527-537

Castellani C, Altunbaş Y (2006) Factors controlling the temporal dynamics of egg production of the copepod Temora longicornis. Mar Ecol Prog Ser 308:143-153

Castellani C, Altunbas Y Temperature response of Temora longicornis (Müller) under field and laboratory conditions. (In preparation)

Castellani C, Robinson C, Smith T, Lampitt RS (2005) Temperature affects respiration rate of Oithona similis. Mar Ecol Prog Ser 285: 129-135

Clarke A (1993) Seasonal acclimatization and latitudinal compensation in metabolism: do they exist? Functional Ecology 7: 139-149

Clarke ME, Walsh PJ (1993) Effect of nutritional status on citrate synthase activity in Acartia tonsa and Temora longicornis. Limnol Oceanogr 38: 414-418

Clarke A, Fraser KPP (2004) Why does metabolism scale with temperature? Functional Ecology 18: 243-251

Conover RJ (1959) Regional and seasonal variation in the respiratory rate of marine copepods. Limnol Oceanog 4:259-68

Conover RJ (1962) Metabolism and growth in Calanus hyperboreus in relation to its life cycle. Rapp P-v Reun Cons Perm Int Explor Mer 153: 190-197

Conover RJ, Corner EDS (1968) Respiration and nitrogen excretion by some zooplankton in relation to their life cycles. JMBA UK 48: 49-75

Cossins AR, Bowler K (1987) Temperature biology of animals. Chapman and Hall, 339 pp.

Dam HG (2013) Evolutionary Adaptation of Marine Zooplankton to Global Change. Ann Rev Mar Sci 5:1-22

Dam HG and Lopes RM (2003) Omnivory in the calanoid copepod Temora longicornis: feeding, egg production and egg hatching rates. J Exp Mar Biol Ecol 292:119-137

Enquist BJ, Economo EP, Huxman TE, Allen AP, Ignace DD, Gillooly GF (2003) Scaling metabolism from organisms to ecosystems. Nature 423:639-642

Evjemo JO, Olsen Y (1997) Lipid and fatty acid content in cultivated live feed organisms compared to marine copepods. Hydrobiologia 358: 159-162. 
Fransz HG, Colebrook JM, Gamble JC, Krause M (1991) The zooplankton of the North Sea. Neth J Sea Res 28:1-52

Gaudy R (1973) Les variations saisonnieres de la respiration chez quatre especes de copepods pelagiques du golfe de Marseille. Neth J of Sea Res 7 : 267-279

Gaudy R, Thibault-Botha D (2007) Metabolism of Centropages typicus in the Mediterranean Sea and the North Atlantic Ocean. Prog Oceanog 72:151-163

Gauld DT, Raymont JEG (1953) The respiration of some planktonic copepods II. The effect of temperature. JMBA UK 31: 447-460

Gillooly JF, Brown JH, West GB, Savage, Charnov EL (2001) Effects of size and temperature on metabolic rate. Science 293: 2248-2251

Glazier DS (2006) The 3/4-Power law is not universal: evolution of isometric, ontogenetic metabolic scaling in pelagic animals. Bioscience 56: 325-332

Glazier DS (2009) Activity affects intraspecific body-size scaling of metabolic rate in ectothermic animals. J Comp Physiol B. 179: 821-8

Glazier DS (2010) A unifying explanation for diverse metabolic scaling in animals and plants. Biol Rev Camb Phil Soc 85: 111-138

Green EJ, Carrit DE (1967) New tables for oxygen saturation of seawater. J Mar Res 25: 140147

Gujarati DN (2010) Basic Econometrics. $5^{\text {th }}$ Revised Edition, McGraw-Hill Publisher, 800 pp

Helland S, Terjesen BF, Berg L (2003) Free amino acid and protein content in the planktonic copepod Temora longicornis compared to Artemia franciscana. Aquaculture 215: 213-228

Hirche H-J (1987) Temperature and plankton. II Effect on respiration and swimming activity in copepods from the Greenland Sea. Mar Biol 94: 347-356

Hirst AG and Bunker AJ (2003) Growth of marine planktonic copepods: global rates and patterns in relation to chlorophyll a, temperature and body weight. Limnol Oceanog 48:1988-2010

Ikeda T, Torres JJ, Hernandez-Leon S, Geiger SP (2000) Metabolism. In: Harris RP, Wiebe PH, Lenz J, Skjoldal HR, Huntley M (eds) ICES zooplankton methodology manual. Academic Press, San Diego, CA, p 455-532

Ikeda T, Kanno Y, Ozaki Y, Shinada A (2001) Metabolic rates of epipelagic marine copepods as a function of body mass and temperature. Mar Biol 139: 587-596

Jónasdóttir SH, Visser AW, Jespersen C (2009) Assessing the role of food quality in the production and hatching of Temora longicornis eggs. Mar Ecol Prog Ser 382:139-150

Kanwisher JW (1959)Polarographic oxygen electrode. Limnol Oceanogr 4: 210-17 
Kiørboe T, Mohlenberg F Hamburger K (1985) Bioenergetics of the planktonic copepod Acartia tonsa: relation between feeding, egg production and respiration and composition of specific dynamic action. Mar Ecol Prog Ser 26: 85-97

Kolokotrones T, Savage V, Deeds EJ, Fontana W (2010) Curvature in metabolic scaling. Nature 464: 753-756

Kreibich T, Saborowski R, Hagen W, Niehoff B (2008) Short-term variation of nutritive and metabolic parameters in Temora longicornis females (Crustacea, Copepoda) as a response to diet shift and starvation. Helgol Mar Res 62: 241-249

Le Ruyet-Person J, Razouls C, Razouls S (1975) Biologie compare entre especes vicariantes et communes de copepods dans un ecosystemme neritique en Mediterranee et en Manche. Vie et Milieu 25: 283-312

Marshall SM, Orr AP (1966) Respiration and feeding in some small copepods. JMBA UK 46: 513-530

Marshall SM, Orr AP (1958) On the biology of Calanus finmarchicus. X. Seasonal changes in oxygen consumption. JMBA UK 37:459-472

Marshall SM, Nicholls, AG, Orr AP (1935) On the biology of Calanus finmarchicus. 6. Oxygen consumption in relation to environmental conditions. Journal of the Marine Biological Association of the United Kingdom 20: 1-27

Mauchline J (1998) The biology of calanoid copepods, Academic Press, 710 pp.

Mayzaud P (1976) Respiration and nitrogen excretion of zooplankton. IV. The influence of starvation on the metabolism and the biochemical composition of some species. Mar Biol 37: $47-58$

Mc Neill S, Lawton JH (1970) Annual production and respiration in animal populations. Nature 225: 472-474

Nobili R, Robinson C, Buitenhuis E and Castellani C (2013) Food quality regulates the metabolism and reproduction of Temora longicornis. (In preparation)

Olonscheck D Hofmann M, Worm B, Schellnhuber HJ (2013) Decomposing the effects of ocean warming on chlorophyll a concentrations into physically and biologically driven contributions, Environ. Res. Lett. 8014043 doi:10.1088/1748-9326/8/1/014043

Omori M, Ikeda T (1984) Methods in marine zooplankton ecology, John Wiley \& Sons, New York, $332 \mathrm{pp}$

Parry GD (1983) The influence of the cost of growth on ectotherm metabolism. J Theor Biol 101: $453-477$

Peters RH (1986) The ecological implication of body size. Cambridge University Press, Cambridge 
Peterson WT (1985) Abundance, age structure and in situ egg production rates of the copepod Temora longicornis in Long Island Sound, New York. Bull. Mar. Sci., 37: 726-738

Pretch H (1958) Concepts of the temperature adaptation of unchanging reaction systems of cold-blooded animals. In Physiological Adaptation (ed. CL Prosser) Amer Assn Adv Science Wash DC 50-78.

Prosser CL, Brown FA (1961) Comparative animal physiology. $2^{\text {nd }}$ ed WB Saunders Co Philadelphia

Raymont JEG (1959) The respiration of some planktonic copepods; III. The oxygen requirements of some american species. Limnol Oceanog 4: 479-491

Royal Meteorological Society, Weather Log 1996-1997

Razouls S (1971) Variation annuelles du metabolisme respiratoire de deux copepods pelagiques: Temora stylifera et Centropages typicus a Banyuls-sur-mer (Golfe du Lion). Vie et Milieu 22: $95-112$

Schmidt-Nielsen K (1990) Animal physiology, adaptation and environment. Cambridge University Press. 699 pp Fourth Edition

Secor SM (2009) Specific dynamic action: a review of the postprandial metabolic response. J Comp Physiol, B 179: 1-56

Somero GN (2012) The physiology of global change: linking patterns to mechanisms.

Ann Rev Mar Sci 4: 39-61.

Somero GN and Hochachka PW (1971) Biochemical adaptation to the environment. Am Zool 11:159-167

Stock C, Dunne J (2010) Controls on the ratio of mesozooplankton production to primary production in marine ecosystems. Deep Sea Research I, 57: 95-112.

Tester PA, Turner RE (1990) How long does it take copepods to make eggs? J Exp Mar Biol Ecol 141: 169-182

Tett P (1987) Plankton. In 'Biological Survey of Estuaries and Coasts', ed Baker J \& Wolff WJ, Cambridge University Press, 280-341.

Thor P (2000) Relationship between specific dynamic action and protein deposition in calanoid copepods. J Exp Mar Biol Ecol 245: 171-182

Thor P (2003) Elevated respiration rates of the neritic copepod Acartia tonsa during recovery from starvation. J Exp Mar Biol Ecol 283: 133- 143

West GB Brown JH and Enquist BJ (1997) A general model for the origin of allometric scaling laws in biology. Science 276: 122-126 


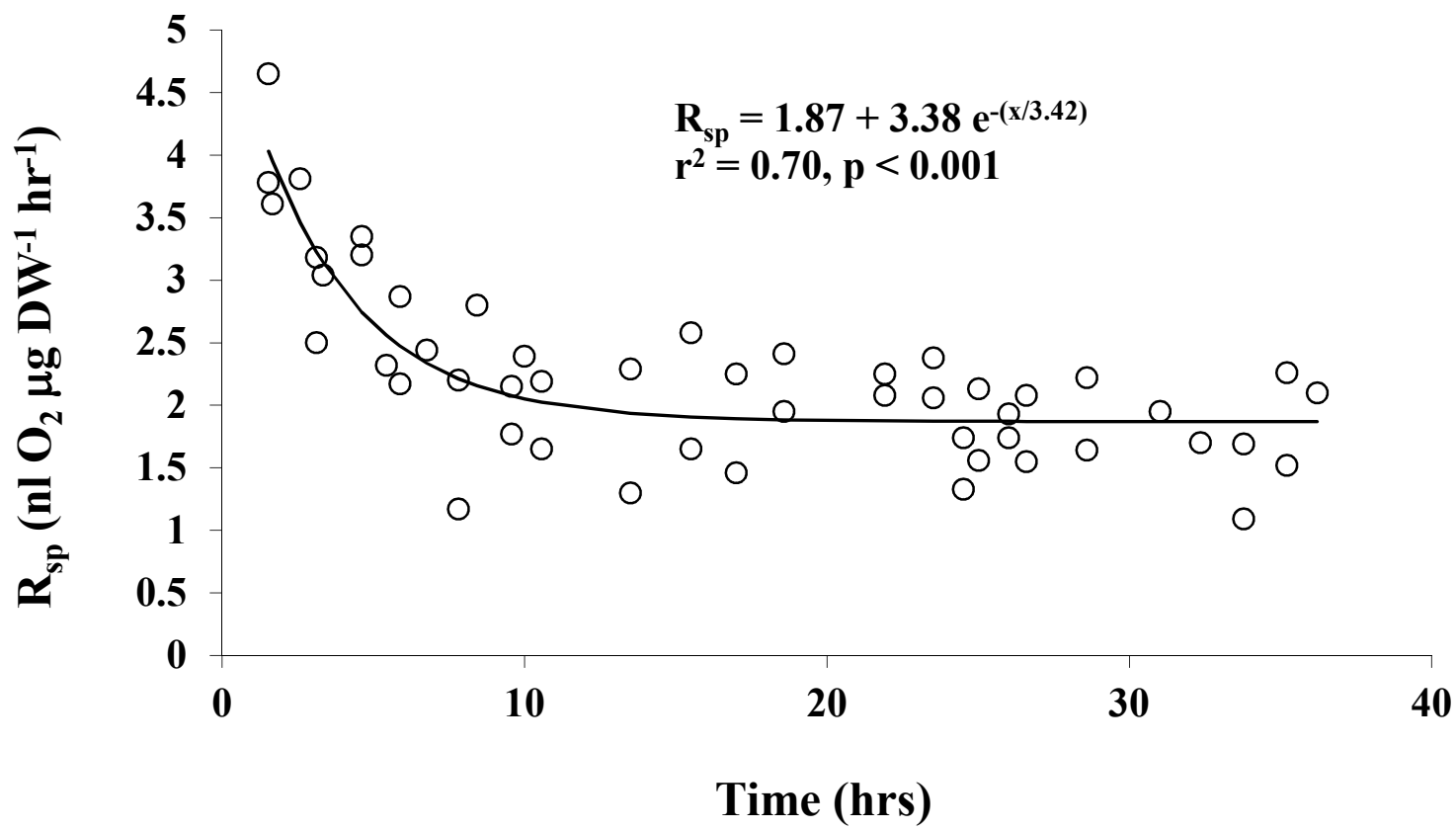

Figure 1: Time course of changes in the weight specific respiration rate $\left(\mathrm{R}_{\mathrm{sp}}, \mathrm{nl} \mathrm{O}_{2} \mu \mathrm{g} \mathrm{DW}^{-1}\right.$ $\mathrm{hr}^{-1}$ ) of fasting $T$. longicornis. Time 0 hours is the time at which copepod were deprived of food.

Time (hrs) 
Figure 2: Seasonal changes in a) temperature $\left.\left(\mathrm{T},{ }^{\circ} \mathrm{C}\right), \mathrm{b}\right)$ chlorophyll-a $\left.\left(\mathrm{Chl}, \mu \mathrm{g} \mathrm{L}{ }^{-1}\right), \mathrm{c}\right)$ respiration rate $\left.\left(\mathrm{nlO}_{2} \operatorname{cop}^{-1} \mathrm{hr}^{-1}\right), \mathrm{d}\right)$ dry weigh $(\mathrm{DW}, \mu \mathrm{g})$ and e) egg production rate (EPR, egg 950 female $\left.^{-1} \mathrm{~d}^{-1}\right)$.

a)

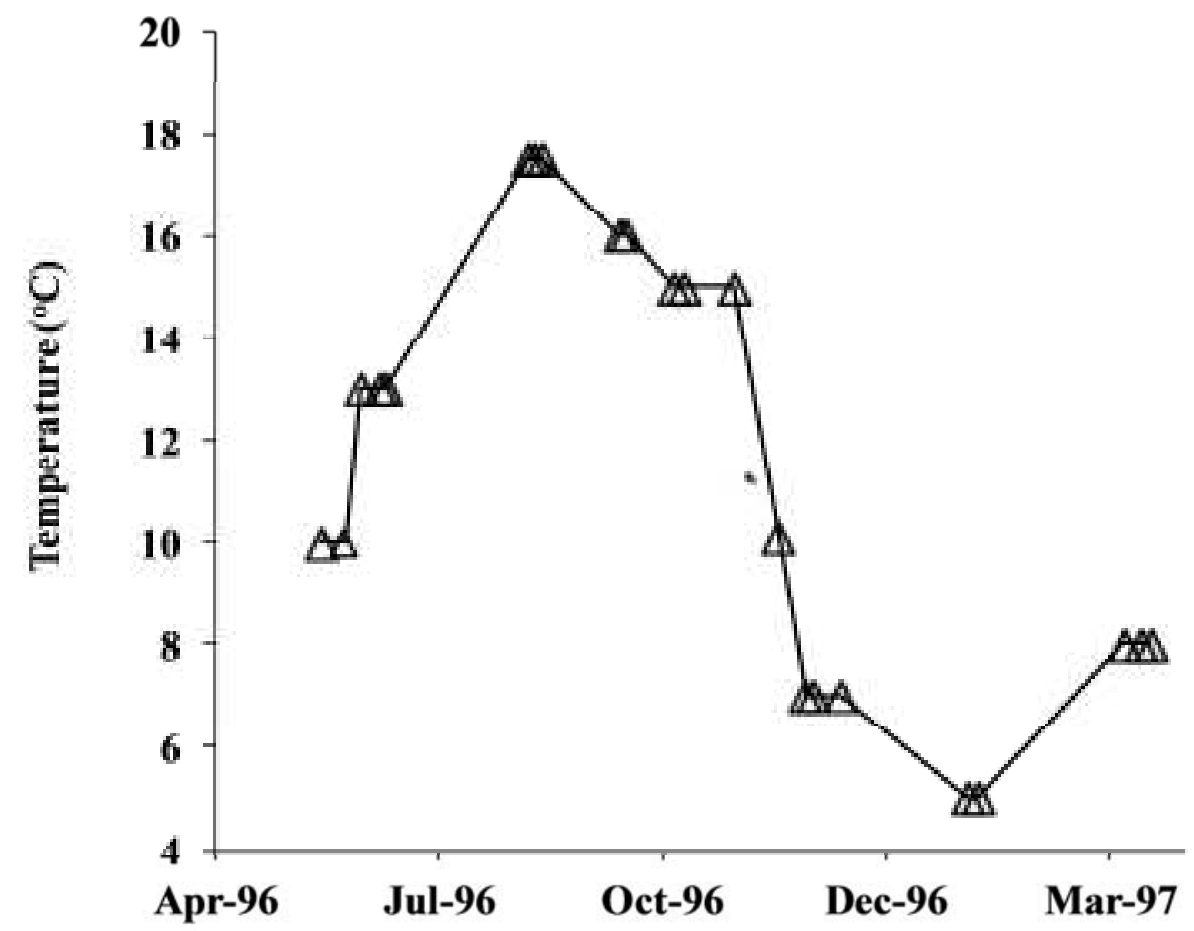

b)

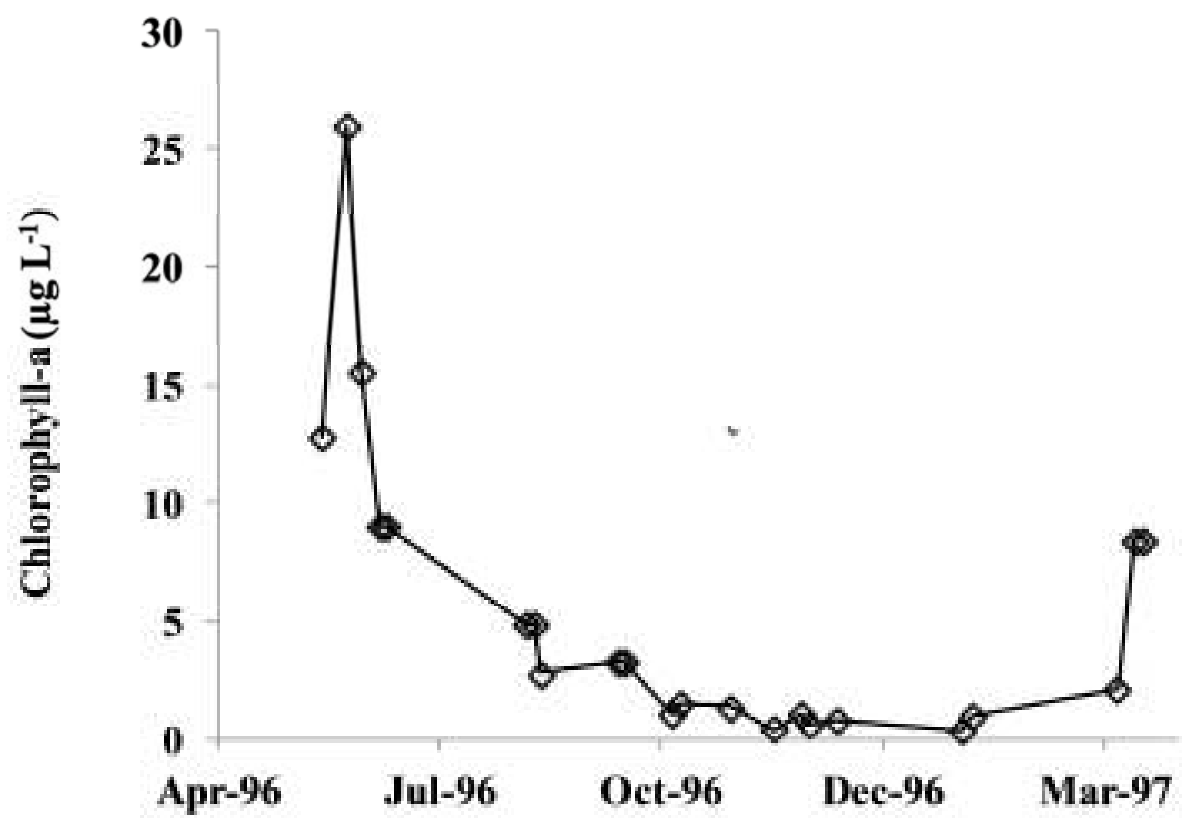


c)

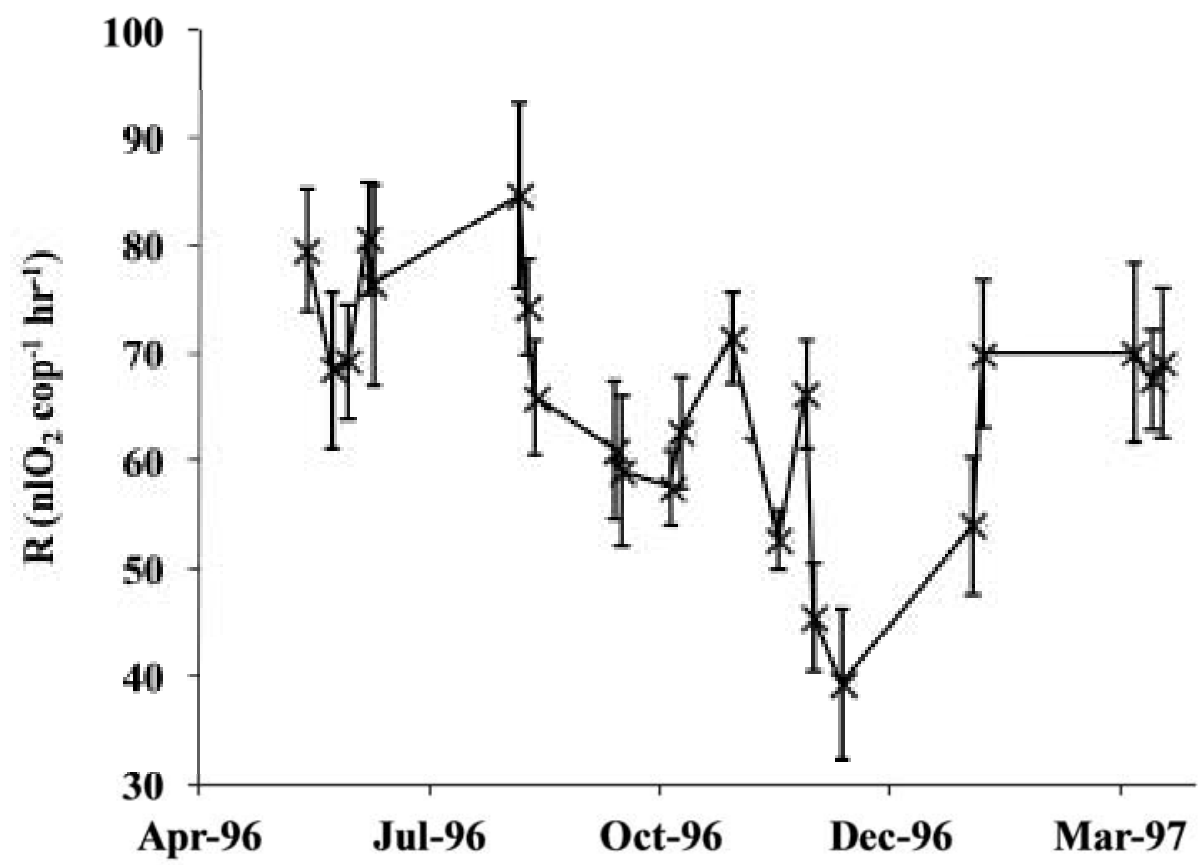

962

963

964

965

966

d)

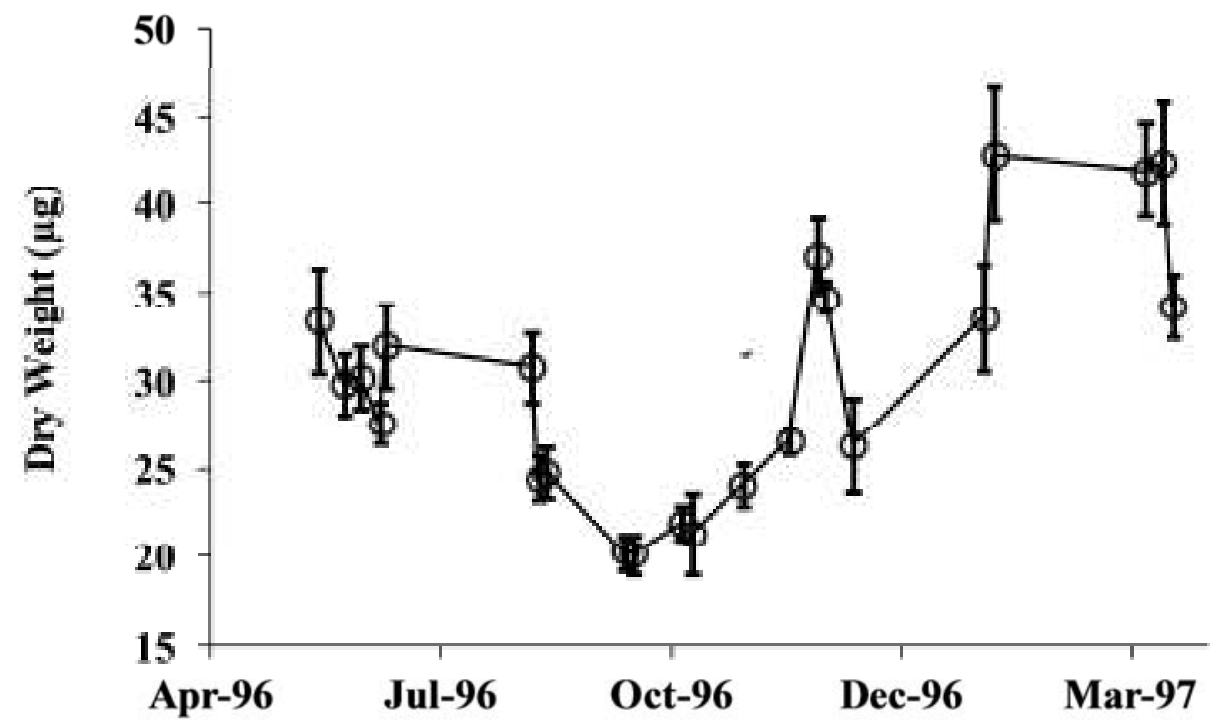


975 e)

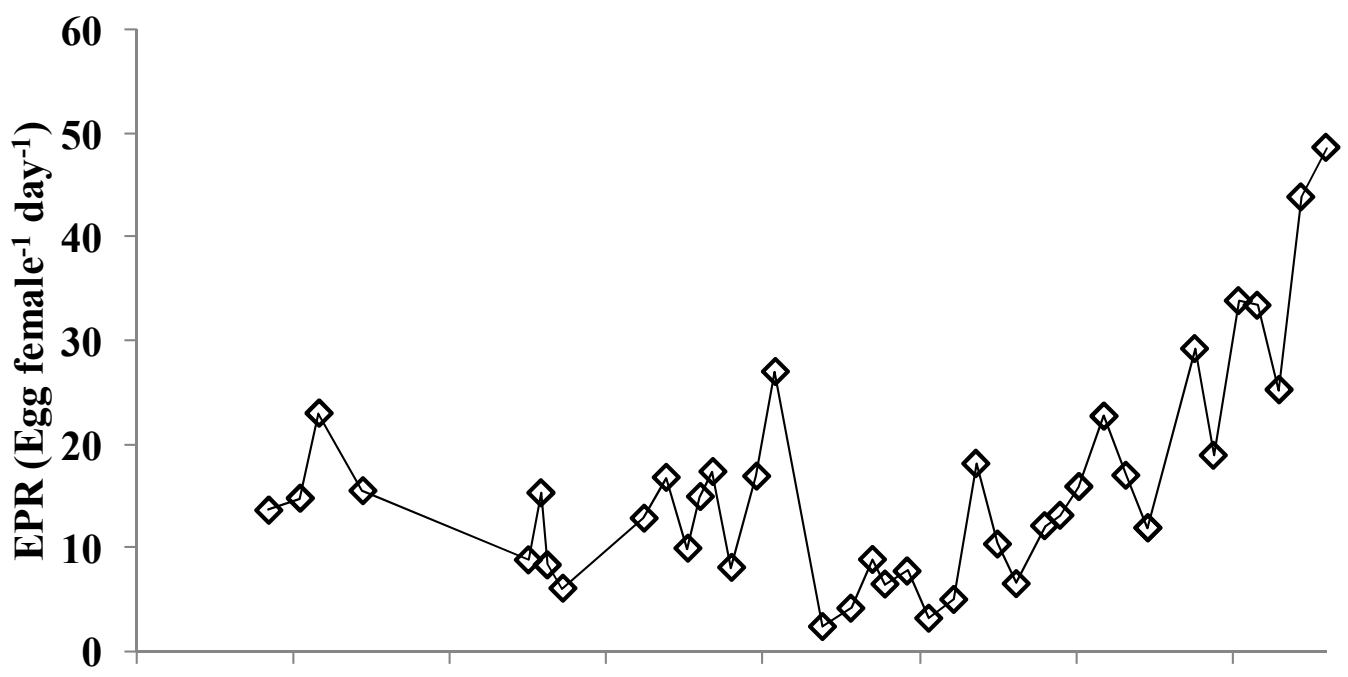

Apr-96 May-96 Jul-96 Sep-96 Oct-96 Dec-96 Jan-97 Mar-97 Month 
978 Figure 3: Scatter plot of ln-transformed respiration rate (ln $\left.\mathrm{R}, \mathrm{nlO}_{2} \operatorname{cop}^{-1} \mathrm{hr}^{-1}\right)$ of $T$. longicornis versus copepod dry weigh $(\ln \mathrm{DW}, \mu \mathrm{g})$. The lines represent fitted values for each temperature obtained from the multiple regression between $\ln \mathrm{R}, \ln \mathrm{DW}$ and temperature $(\mathrm{T}$,

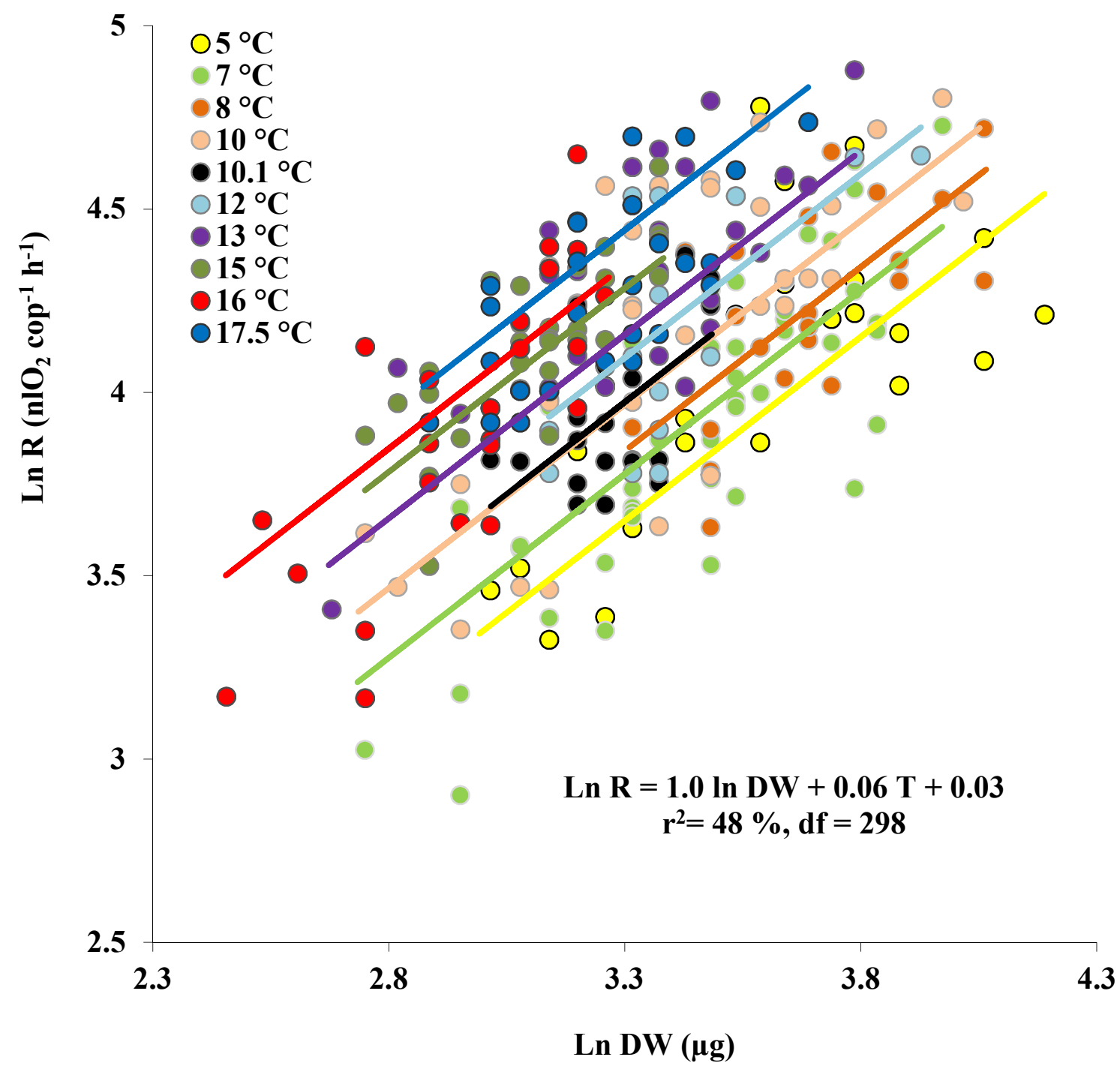


Figure 4: Scatter plot of weight specific respiration rate $\left(\mathrm{R}_{\mathrm{sp}}, \mathrm{nlO}_{2} \mu \mathrm{g} \mathrm{DW}^{-1} \mathrm{hr}^{-1}\right)$ of $T$. longicornis versus temperature $\left(\mathrm{T},{ }^{\circ} \mathrm{C}\right)$. The $\mathrm{Q}_{10}$ values calculated from the regressions in Table 2 for the temperature intervals $5^{\circ} \mathrm{C}$ to $7^{\circ} \mathrm{C}, 8{ }^{\circ} \mathrm{C}$ to $13^{\circ} \mathrm{C}$ and $15^{\circ} \mathrm{C}$ to $17.5^{\circ} \mathrm{C}$ are also shown. The continuous line represents the logistic function fitted to the data.

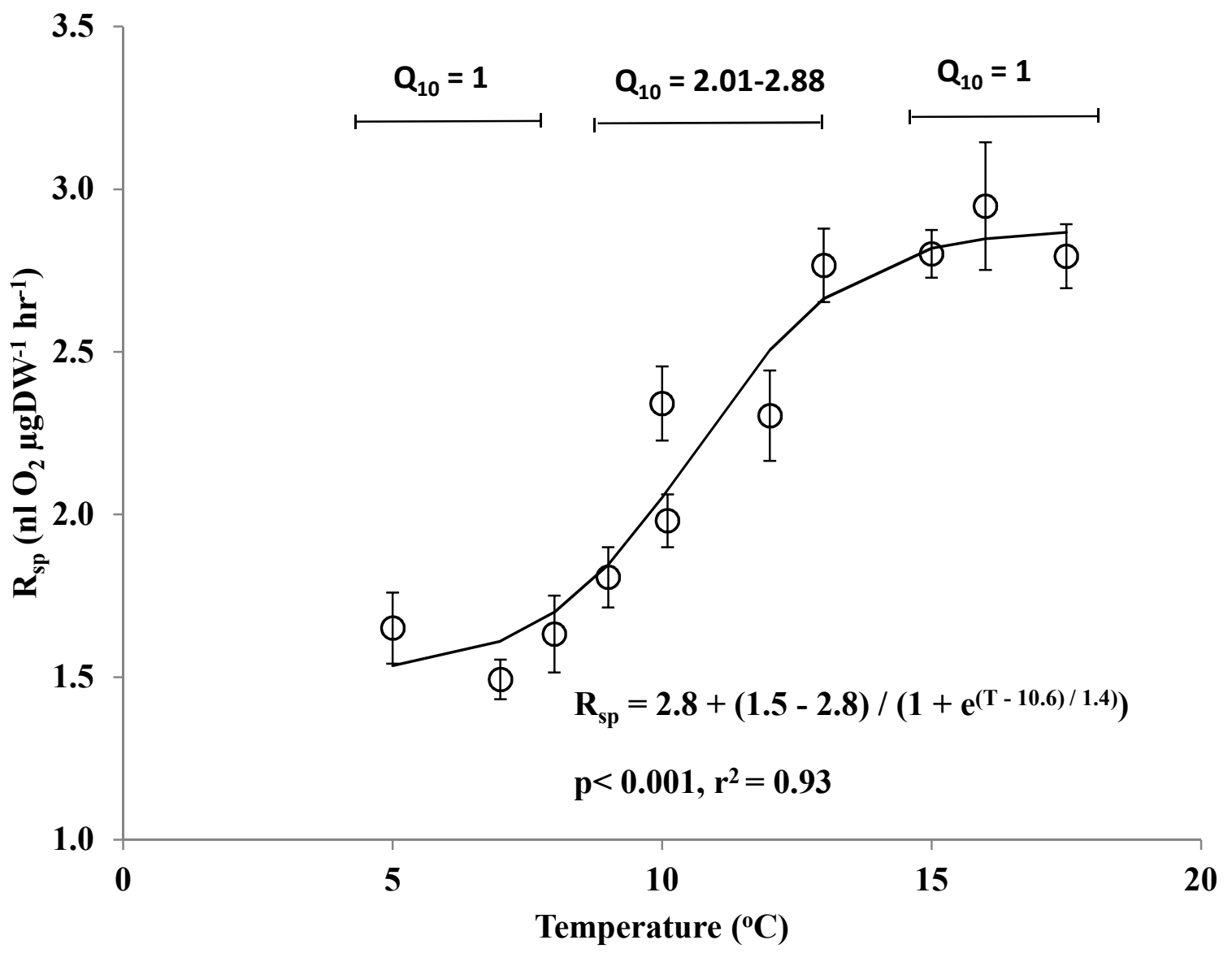


1000 Figure 5: Scatter plot of the respiration rate $\left(\ln \mathrm{R}, \mathrm{nlO}_{2} \operatorname{cop}^{-1} \mathrm{hr}^{-1}\right)$ of T. longicornis versus 1001 chlorophyll-a (Chl, $\left.\mu \mathrm{g} \mathrm{L}^{-1}\right)$.

1002

1003

1004

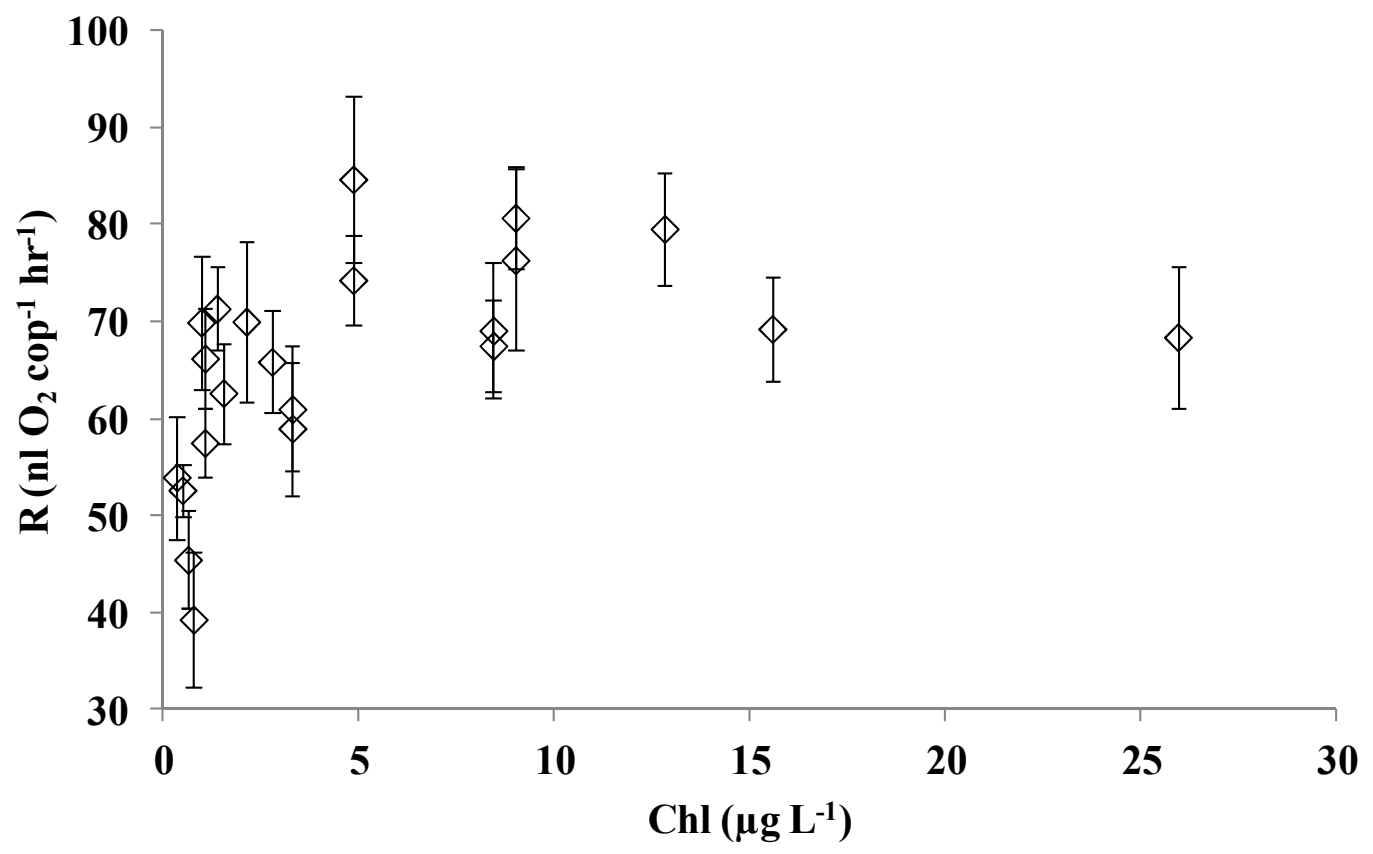


1008 Figure 6: Scatter plot of the respiration rate $\left(\ln \mathrm{R}, \mathrm{nlO}_{2} \operatorname{cop}^{-1} \mathrm{hr}^{-1}\right)$ of $T$. longicornis versus egg 1009 production rate (EPR, egg female $\mathrm{d}^{-1}$ ).

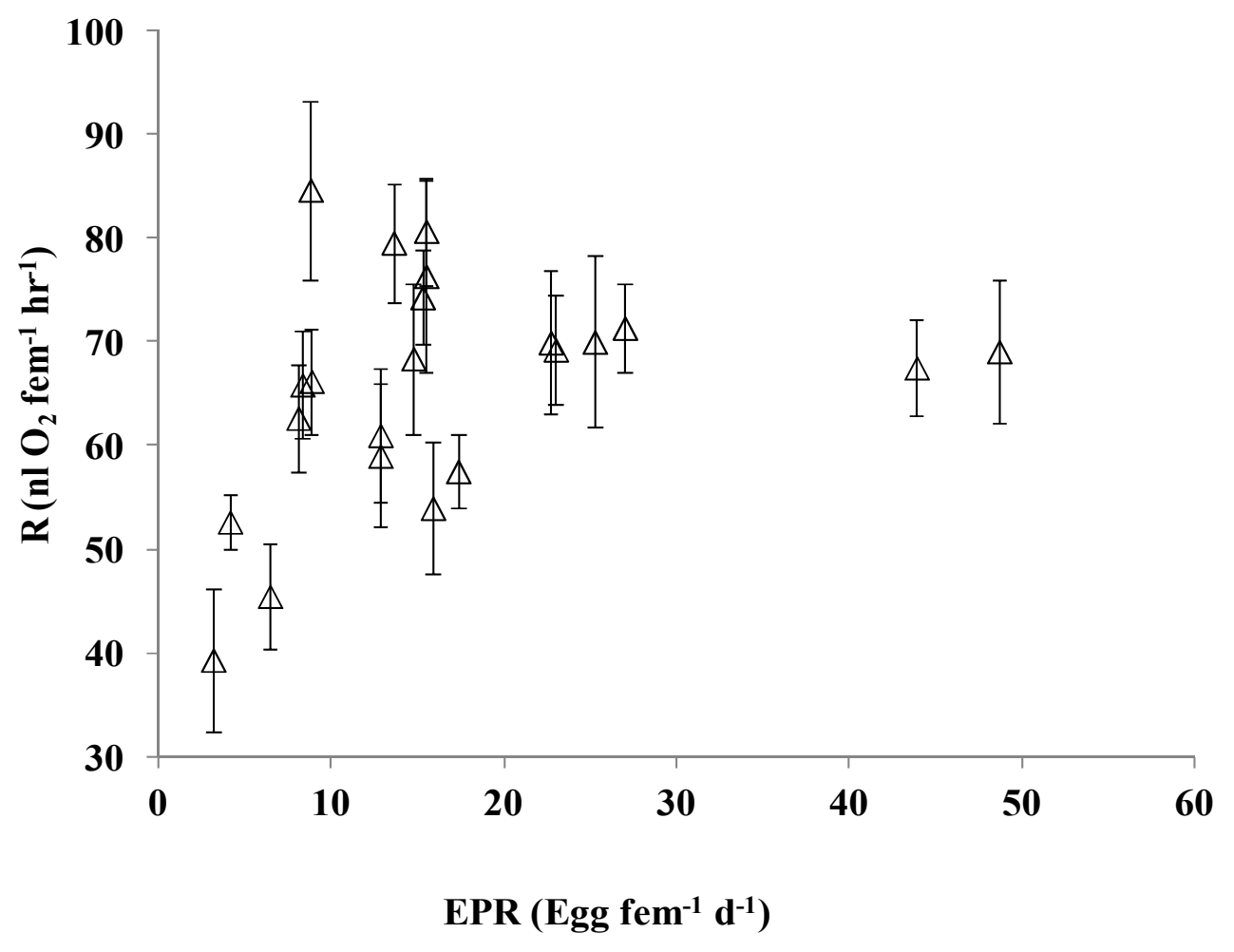


1012 Figure 7: Scatter plot comparing of the respiration rate ( $\left.\ln \mathrm{R}, \mathrm{nlO}_{2} \mathrm{cop}^{-1} \mathrm{hr}^{-1}\right)$ of $T$.

1013 longicornis versus prosome length (PL, $\mu \mathrm{m}$ ) obtained by different field studies (See Table 5)

1014

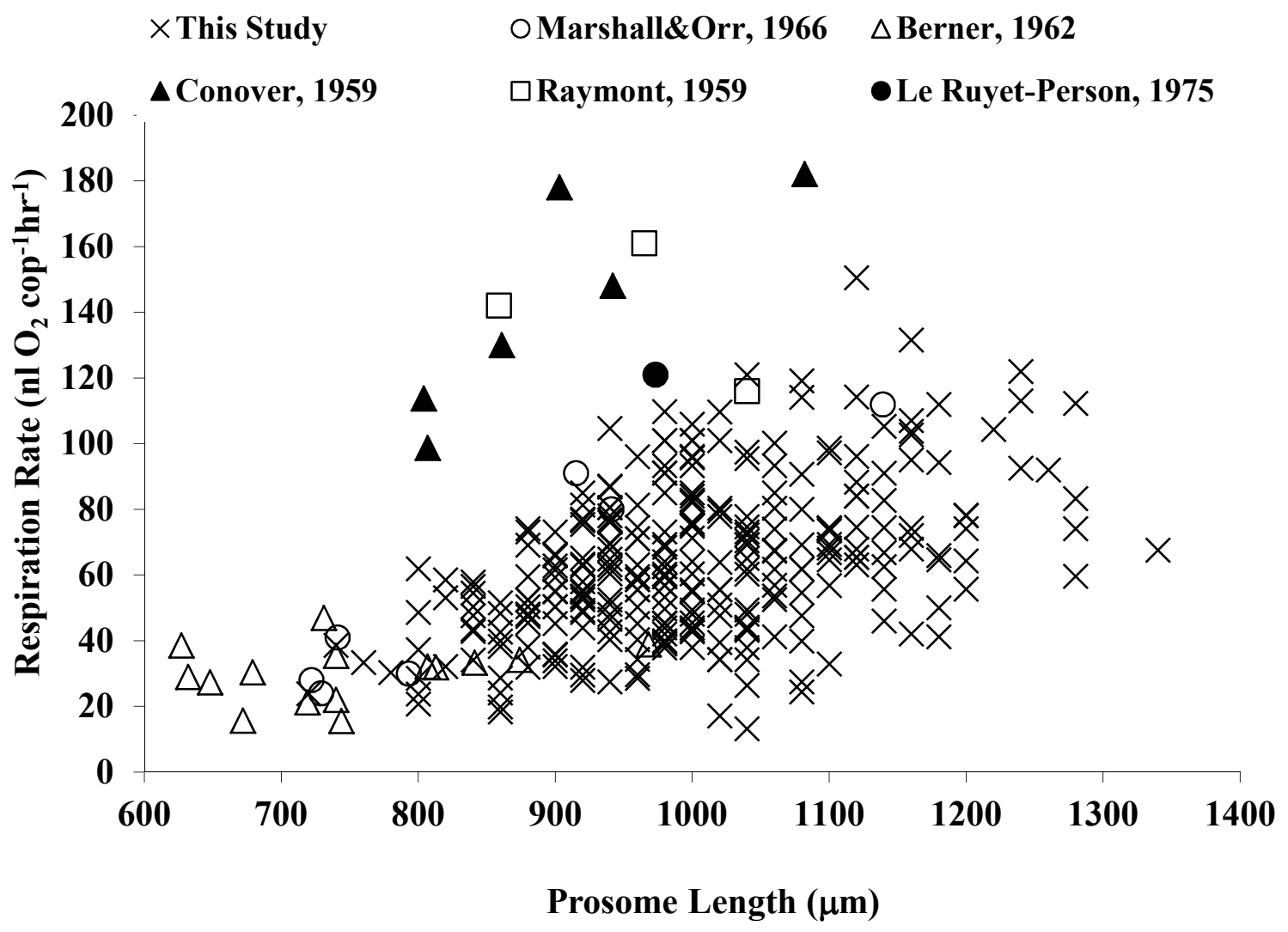


1018 Figure 8: Scatter plot comparing of the respiration rate (ln $\left.\mathrm{R}, \mathrm{nlO}_{2} \operatorname{cop}^{-1} \mathrm{hr}^{-1}\right)$ of $T$.

1019 longicornis versus temperature $\left(\mathrm{T},{ }^{\circ} \mathrm{C}\right)$ obtained by different field studies (See Table 5). (ln $\left.1020 \mathrm{R}, \mathrm{nlO}_{2} \operatorname{cop}^{-1} \mathrm{hr}^{-1}\right)$.

1021

$\times$ This Study

$\square$ Raymont, 1959

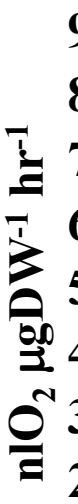

1

9
8
7
6
5
4
3
2
1
0

$\mathbf{0}$

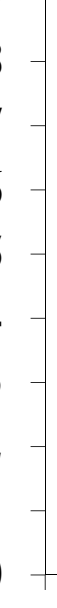

OMarshall\& Orr, 1966

$\triangle$ Conover, 1959 $\triangle$ Berner, 1962

- Le Ruyet-Person, 1975

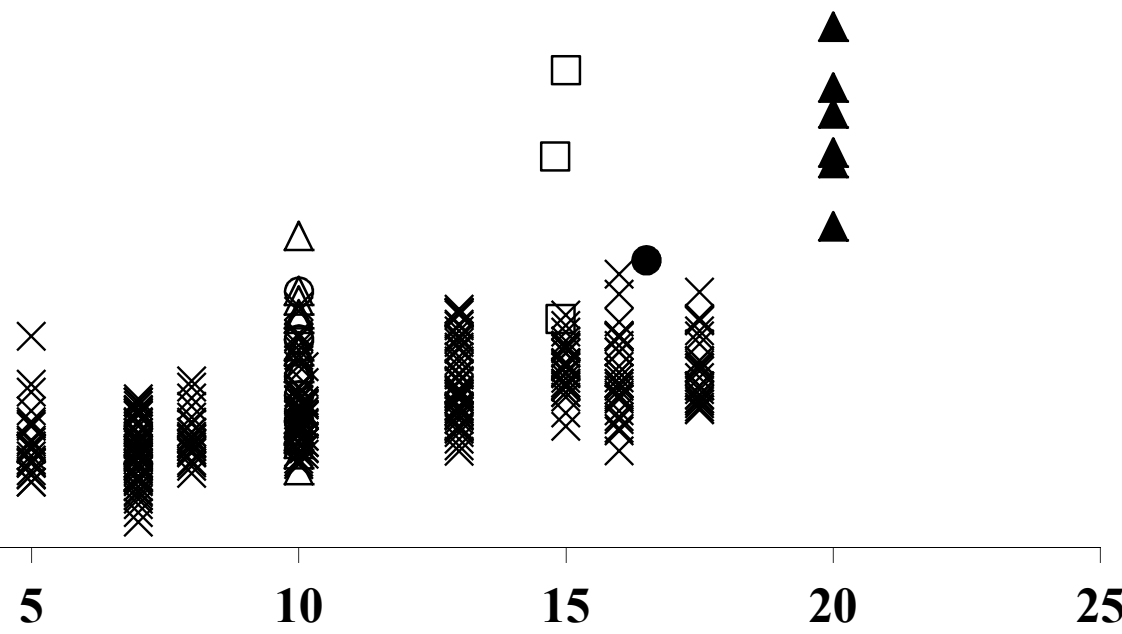

Temperature $\left({ }^{\circ} \mathrm{C}\right)$ 
a)

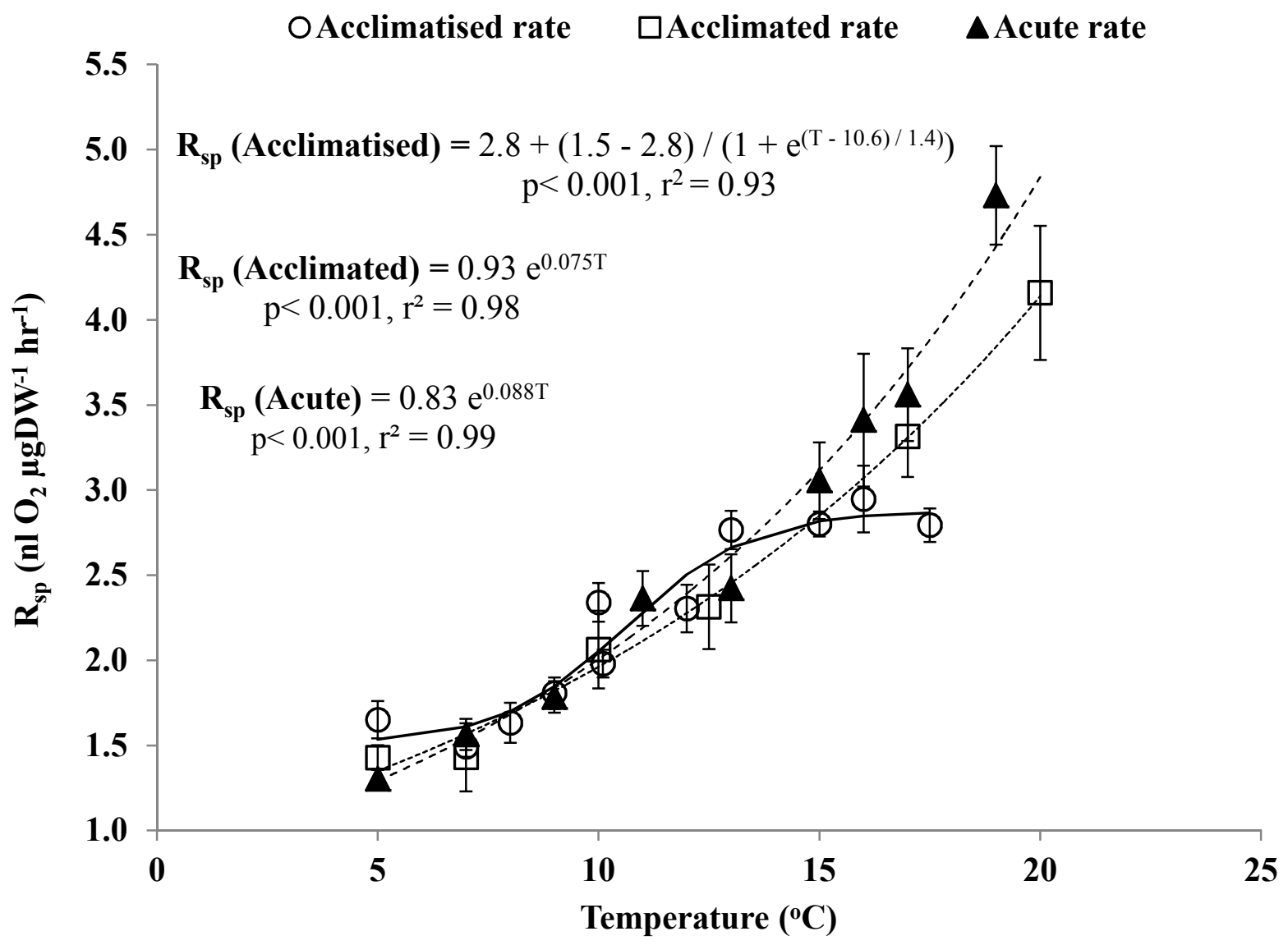

Figure 9: Scatter plot of acclimatised, acclimated and acute mean $( \pm \mathrm{SE})$ weight specific respiration rates $\left(\mathrm{R}_{\mathrm{sp}}, \mathrm{nlO}_{2} \mu \mathrm{gDW} \mathrm{hr}{ }^{-1}\right)$ of $T$. longicornis versus a) temperature $\left({ }^{\circ} \mathrm{C}\right)$ and $\left.\mathrm{b}\right)$ the inverse of the absolute temperature $(1 / \mathrm{K})$ i.e. the Arrhenius plot. Lines represent the fits from the regressions models. 
1036

1037

1038

b)

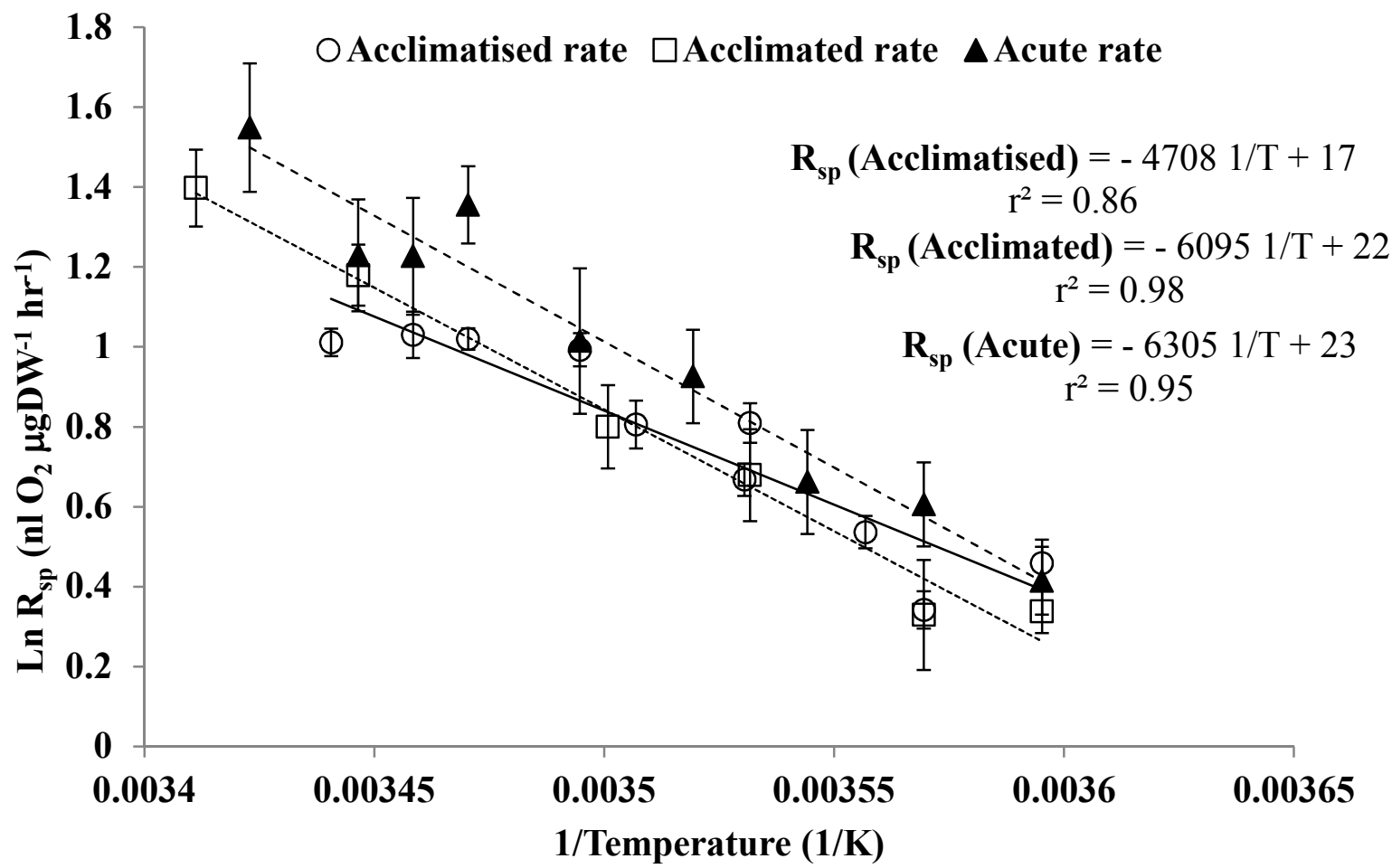


1045 Figure 10: Scatter plot of weight specific egg production rate $\left(\mathrm{EPR}_{\mathrm{sp}}, \mathrm{d}^{-1}\right)$ of $T$. longicornis 1046 versus in situ temperature $\left({ }^{\circ} \mathrm{C}\right)$.

1047

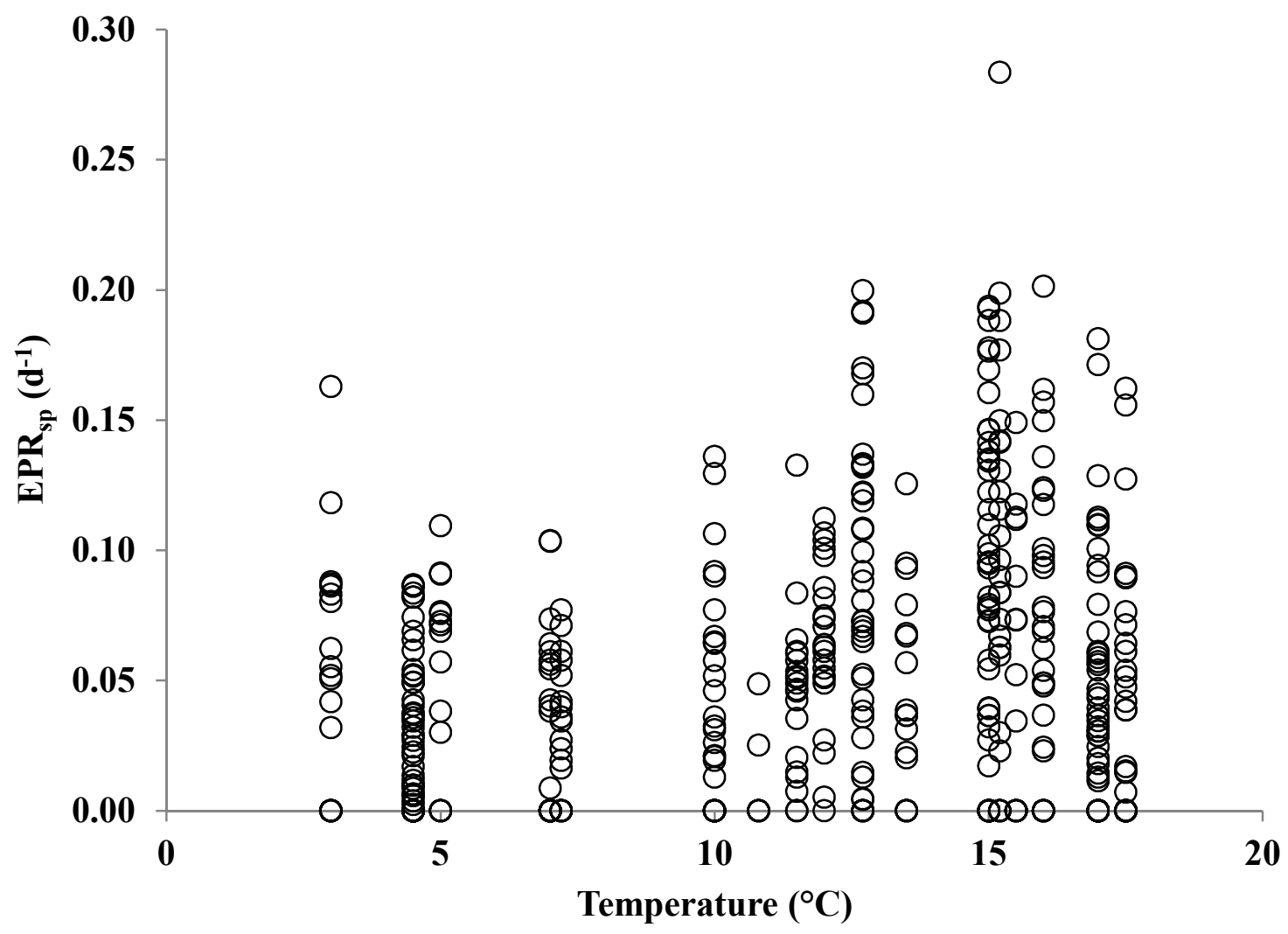


Table 1: Sampling dates for T. longicornis used for the respiration rates experiments and corresponding environmental variables

\begin{tabular}{|c|c|c|c|}
\hline $\begin{array}{l}\text { Sampling } \\
\text { Date }\end{array}$ & $\begin{array}{c}\mathbf{T} \\
\left({ }^{\circ} \mathbf{C}\right)\end{array}$ & Salinity & $\underset{\left(\mu \mathrm{g} \mathrm{L} \mathrm{L}^{-1}\right)}{\text { Chla }}$ \\
\hline 17/05/1996 & 10.0 & 34 & 12.80 \\
\hline 27/05/1996 & 10.0 & 34 & 25.92 \\
\hline 02/06/1996 & 12.0 & 34 & 15.55 \\
\hline 10/06/1996 & 13.0 & 34 & 8.99 \\
\hline $12 / 06 / 1996$ & 13.0 & 34 & 8.99 \\
\hline 08/08/1996 & 17.5 & 33.8 & 4.84 \\
\hline 11/08/1996 & 17.5 & 33.8 & 4.84 \\
\hline $14 / 08 / 1996$ & 17.5 & 33.8 & 2.76 \\
\hline 14/09/1996 & 16.0 & 34 & 3.28 \\
\hline 17/09/1996 & 16.0 & 34 & 3.28 \\
\hline 06/10/1996 & 15.0 & 33.7 & 1.05 \\
\hline 10/10/1996 & 15.0 & 33.7 & 1.52 \\
\hline 30/10/1996 & 15.0 & 33.7 & 1.35 \\
\hline 17/11/1996 & 10.1 & 33.6 & 0.48 \\
\hline 28/11/1996 & 7.0 & 31.76 & 1.05 \\
\hline 01/12/1996 & 7.0 & 33.1 & 0.62 \\
\hline $12 / 12 / 1996$ & 7.0 & 33.6 & 0.76 \\
\hline 01/02/1997 & 5.0 & 33.04 & 0.33 \\
\hline 05/02/1997 & 5.0 & 33.04 & 0.95 \\
\hline 05/04/1997 & 8.0 & 33.8 & 2.11 \\
\hline $12 / 04 / 1997$ & 8.0 & 33.7 & 8.42 \\
\hline $16 / 04 / 1997$ & 9.0 & 33.7 & 8.42 \\
\hline
\end{tabular}


Table 2: Multiple regression analysis between $\ln$-transformed T. longicornis respiration rate (ln $\mathrm{R}, \mathrm{nlO}_{2} \operatorname{cop}^{-1} \mathrm{hr}^{-1}$ ) with copepod body dry weight (ln $\mathrm{DW}$, $\mu \mathrm{g}$ ) in situ

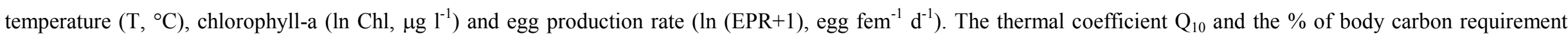
calculated from the equation models is also shown. Note that the $\mathrm{F}$ test for all regression models is statistically significant at $1 \%$ level. The *, $* *$, and $* * *$ symbols indicate 1057 statistical significance of the variables at the $10 \%, 5 \%$ and $1 \%$ levels respectively.

1058 a)

\begin{tabular}{|c|c|c|c|c|c|c|c|c|c|c|c|c|}
\hline Regression Model & $\ln$ DW & $\mathbf{T}$ & $\ln \mathbf{C h l}$ & $(\mathbf{E P R}+1)$ & Intercept & $\mathbf{N}$ & $\mathbf{r}^{2}$ & F-value & $\mathbf{Q}_{10}$ & \% body-C & & \\
\hline Temperature range: $5^{\circ} \mathrm{C}-17.5^{\circ} \mathrm{C}$ & & & & & & & & & & $5^{\circ} \mathrm{C}$ & $10{ }^{\circ} \mathrm{C}$ & $17.5^{\circ} \mathrm{C}$ \\
\hline \multirow[t]{2}{*}{ 1) $\ln R=1.00 \ln \mathrm{DW}+0.06 \mathrm{~T}+0.03$} & $1.00 * * *$ & $0.06 * * *$ & & & 0.03 & 299 & 47.6 & 180.94 & 1.89 & 4.46 & 6.02 & 9.16 \\
\hline & $(0.056)$ & $(0.005)$ & & & $(0.218)$ & & & & & & & \\
\hline \multirow[t]{2}{*}{ 2) $\ln \mathrm{R}=0.96 \ln \mathrm{DW}+0.06 \mathrm{~T}+0.05 \ln \mathrm{Chl}+0.21$} & $0.96 * * *$ & $0.06 * * *$ & $0.05 * * *$ & & 0.21 & 299 & 49.6 & 124.40 & 1.75 & 4.51 & 7.25 & 10.25 \\
\hline & $(0.058)$ & $(0.005)$ & $(0.014)$ & & $(0.225)$ & & & & & & & \\
\hline \multirow[t]{2}{*}{ 3) $\ln \mathrm{R}=0.87 \ln \mathrm{DW}+0.05 \mathrm{~T}+0.05 \ln \mathrm{Ch} \mathrm{l}+0.04 \ln (\mathrm{EPR}+1)+0.56$} & $0.87^{* * *}$ & $0.05 * * *$ & $0.05 * *$ & $0.04 * *$ & 0.56 & 188 & 43.9 & 36.79 & 1.57 & 4.75 & 7.62 & 9.90 \\
\hline & $(0.099)$ & $(0.007)$ & $(0.020)$ & $(0.017)$ & $(0.377)$ & & & & & & & \\
\hline \multicolumn{13}{|l|}{ Temperature range: $8-13{ }^{\circ} \mathrm{C}$} \\
\hline \multirow[t]{2}{*}{ 4) $\ln R=1.04 \ln \mathrm{DW}+0.11 \mathrm{~T}-0.50$} & $1.04 * * *$ & $0.11 * * *$ & & & $-0.50 *$ & 189 & 53.2 & 146.81 & 2.88 & & 18.2 & \\
\hline & $(0.067)$ & $(0.010)$ & & & $(0.272)$ & & & & & & & \\
\hline \multirow[t]{2}{*}{ 5) $\ln \mathrm{R}=1.00 \ln \mathrm{DW}+0.09 \mathrm{~T}+0.05 \ln \mathrm{Chl}-0.25$} & $1.00 * * *$ & $0.09 * * *$ & $0.05 * * *$ & & -0.25 & 189 & 54.7 & 99.33 & 2.39 & & 7.07 & \\
\hline & $(0.071)$ & $(0.011)$ & $(0.017)$ & & $(0.290)$ & & & & & & & \\
\hline \multirow[t]{2}{*}{ 6) $\ln \mathrm{R}=0.83 \ln \mathrm{DW}+0.07 \mathrm{~T}+0.06 \ln \mathrm{Ch} \mathrm{l}+0.03 \ln (\mathrm{EPR}+1)+0.46$} & $0.83 * * *$ & $0.07 * * *$ & $0.06 * *$ & 0.03 & 0.46 & 121 & 52.5 & 32.35 & 2.01 & & 6.83 & \\
\hline & $(0.119)$ & $(0.014)$ & $(0.025)$ & $(0.021)$ & $(0.474)$ & & & & & & & \\
\hline
\end{tabular}




\begin{tabular}{|c|c|c|c|c|c|c|c|c|c|c|}
\hline & $\ln \mathrm{DW}$ & $1 / \mathbf{K}$ & In Chl & $(\mathrm{EPR}+1)$ & Intercept & $\mathbf{N}$ & $\mathbf{r}^{2}$ & F-value & Ea & \\
\hline Temperature range: $5^{\circ} \mathrm{C}-17.5^{\circ} \mathrm{C}$ & & & & & & & & & KJ mol-1 & eV \\
\hline \multirow[t]{2}{*}{ 7) $\ln \mathrm{R}=0.99 \mathrm{Ln} \mathrm{DW}-5163 / \mathrm{KT}+18.9$} & $0.99 * * *$ & $-5163 * * *$ & & & 18.9 & 299 & 47.8 & 180.16 & 42.93 & 0.45 \\
\hline & $(0.055)$ & $(385.64)$ & & & 1.28 & & & & & \\
\hline \multirow[t]{2}{*}{ 8) $\ln \mathrm{R}=0.95 \mathrm{Ln} \mathrm{DW}-4585 / \mathrm{KT}+0.05 \ln \mathrm{Chl}+16.9$} & $0.95 * * *$ & $-4585 * * *$ & $0.045 * * *$ & & 16.89 & 299 & 49.5 & 122.25 & 38.12 & 0.39 \\
\hline & 0.058 & 395.83 & 0.014 & & 1.31 & & & & & \\
\hline \multirow[t]{2}{*}{ 9) $\ln \mathrm{R}=0.85 \mathrm{Ln} \mathrm{DW}-3670 / \mathrm{KT}+0.05 \ln \mathrm{Ch} 1+0.03 \ln (\mathrm{EPR}+1)+14.01$} & $0.85 * * *$ & $-3670 * * *$ & $0.046^{* *}$ & $0.034 * *$ & 14.01 & 188 & 35.8 & 43.7 & 30.51 & 0.31 \\
\hline & 0.099 & 570 & 0.0198 & 0.0169 & 1.83 & & & & & \\
\hline \multicolumn{11}{|l|}{ Temperature range: $8-13^{\circ} \mathrm{C}$} \\
\hline \multirow[t]{2}{*}{ 10) $\ln \mathrm{R}=1.01 \mathrm{Ln} \mathrm{DW}-8627 / \mathrm{KT}+31.1$} & $1.01 * * *$ & $-8627 * * *$ & & & 31.09 & 189 & 53.6 & 144.02 & 71.72 & 0.74 \\
\hline & 0.067 & 812 & & & 2.83 & & & & & \\
\hline \multirow[t]{2}{*}{ 11) $\ln \mathrm{R}=0.99 \mathrm{Ln} \mathrm{DW}-7259 / \mathrm{KT}+0.04 \ln \mathrm{Chl}+26.3$} & $0.989 * * *$ & $-7259 * * *$ & $0.041^{* *}$ & & 26.3 & 189 & 54.6 & 96.9 & 60.35 & 0.63 \\
\hline & 0.071 & 912 & 0.0177 & & 3.15 & & & & & \\
\hline \multirow[t]{2}{*}{ 12) $\ln \mathrm{R}=0.81 \mathrm{Ln} \mathrm{DW}-5740 / \mathrm{KT}+0.05 \ln \mathrm{Chl}+0.03 \ln (\mathrm{EPR}+1)+21.48$} & $0.81 * * *$ & $-5740 * * *$ & $0.054 * *$ & 0.026 & 21.48 & 121 & 31.66 & 52.3 & 47.72 & 0.49 \\
\hline & 0.11 & 1182 & 0.025 & 0.021 & 4.02 & & & & & \\
\hline
\end{tabular}


Table 3: Summary of regression analysis between $T$. longicornis $\ln$-transformed respiration rate $\left(\ln \mathrm{R}_{,} \mathrm{nlO}_{2} \operatorname{cop}^{-1} \mathrm{hr}^{-1}\right)$ and body dry weight $(\mathrm{ln} \mathrm{DW}$, $\mu \mathrm{g})$. The temperature $(\mathrm{T}$, $\left.{ }^{\circ} \mathrm{C}\right)$ at which respiration rate was measured, the number of measurements (N), the mean (SD) copepod prosome length (PL, $\left.\mu \mathrm{m}\right), \mathrm{DW}$ and $\mathrm{R}$ are also shown. The $*$, **, and

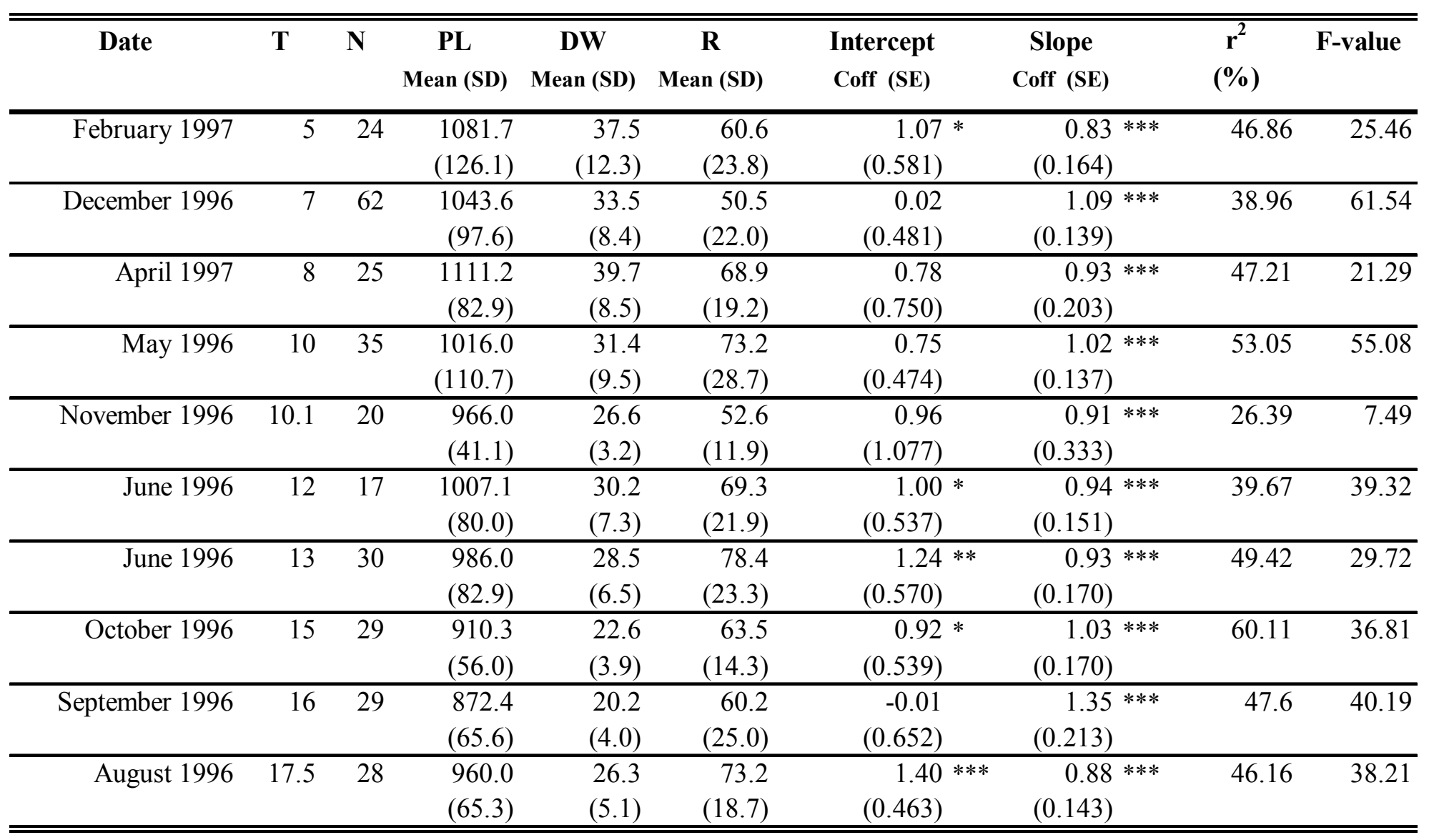




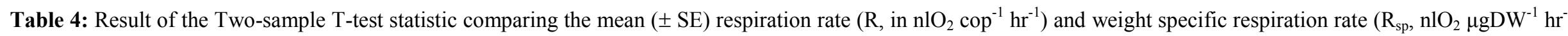

1086

${ }^{1}$ ) of individual $(\mathrm{N})$ females and males T. longicornis of similar prosome length $(\mathrm{PL}, \mu \mathrm{m})$ and dry weight $(\mathrm{DW}, \mu \mathrm{g})$ at $6.5^{\circ} \mathrm{C}$.

1087

\begin{tabular}{llllll}
\hline Gender & $\mathbf{N}$ & $\mathbf{P L}$ & $\mathbf{D W}$ & $\mathbf{R}$ & $\mathbf{R}_{\text {sp }}$ \\
\hline \multirow{2}{*}{ Female } & \multirow{2}{*}{13} & 1060 & 34.4 & 65.9 & 1.91 \\
& & $( \pm 10.4)$ & $( \pm 0.93)$ & $( \pm 4.4)$ & $( \pm 0.11)$ \\
\hline \multirow{2}{*}{ Male } & \multirow{2}{*}{15} & 1048 & 33.32 & 56 & 1.68 \\
& & $( \pm 9.11)$ & $( \pm 0.81)$ & $( \pm 5.1)$ & $( \pm 0.15)$ \\
\hline t-value & & & & 1.48 & 1.23 \\
p-value & & & & 0.15 & 0.23 \\
\hline
\end{tabular}

1088 
Table 5: Summary of $T$. longicornis respiration rates $\left(\mathrm{R}, \mathrm{nlO}_{2} \mathrm{cop}^{-1} \mathrm{hr}^{-1}\right)$ measured during either field ${ }^{1}$ or laboratory experiments ${ }^{2}$. Prosome length $(\mathrm{PL}, \mu \mathrm{m})$, dry weigh (DW, $\mu \mathrm{g})$, length of time copepods were fasting prior to experiment (FT, hrs), respirometer volume (RV, ml), number of copepods incubated $(\mathrm{Cop}, \mathrm{N})$, experimental temperature $\left(\mathrm{ET},{ }^{\circ} \mathrm{C}\right)$, acclimation temperature $\left(\mathrm{AT},{ }^{\circ} \mathrm{C}\right)$.

\begin{tabular}{|c|c|c|c|c|c|c|c|c|c|}
\hline $\begin{array}{c}\text { PL } \\
(\mu \mathrm{m})\end{array}$ & $\begin{array}{l}\text { DW } \\
(\mu \mathrm{g})\end{array}$ & $\begin{array}{l}\text { FT } \\
\text { (hr) }\end{array}$ & $\begin{array}{l}\text { RV } \\
\text { (ml) }\end{array}$ & $\begin{array}{l}\text { Cop } \\
\text { (N) }\end{array}$ & $\begin{array}{l}\text { ET } \\
\left({ }^{\circ} \mathbf{C}\right)\end{array}$ & $\begin{array}{l}\text { AT } \\
\left({ }^{\circ} \mathbf{C}\right)\end{array}$ & $\begin{array}{c}\mathrm{R} \\
\left(\mathrm{nlO}_{2} \operatorname{cop}^{-1} \mathrm{hr}^{-1}\right)\end{array}$ & $\begin{array}{c}\text { Method } \\
\text { [Incubation Time] }\end{array}$ & Source \\
\hline $\begin{array}{l}720- \\
1340\end{array}$ & $12-66^{(\mathbf{a})}$ & $9-12$ & 0.15 & 1 & $5-17.5$ & $\begin{array}{c}5-17.5 \\
\text { [Jan-Dec] }\end{array}$ & $\begin{array}{c}13-150 \\
{[66]}\end{array}$ & $\begin{array}{c}\text { Micro-electrode } \\
{[1 \mathrm{hr}]}\end{array}$ & $\begin{array}{l}{ }^{\mathrm{l}} \text { Present Study, } \\
\text { Menai Strait, UK }\end{array}$ \\
\hline 973 & $27^{(\mathbf{a})}$ & 24 & 0.07 & 1 & $16-17$ & $\begin{array}{l}\text { 16-17 } \\
\text { [July] }\end{array}$ & $\begin{array}{l}87-186 \\
{[121]^{(\mathrm{c})}}\end{array}$ & $\begin{array}{c}\text { Clark-electrode } \\
{[2-6 \mathrm{hrs}]}\end{array}$ & $\begin{array}{l}{ }^{\mathrm{T}} \text { Le Ruyet-Person } \\
\text { et al (1975), } \\
\text { Roscoff, France }\end{array}$ \\
\hline $594-968$ & $7-27^{(\mathbf{a})}$ & 24 & $7-35$ & $1-10$ & 10 & $\begin{array}{c}- \\
\text { [April- } \\
\text { Sept] }\end{array}$ & $\begin{array}{l}16-47 \\
{[32.1]}\end{array}$ & $\begin{array}{c}\text { Winkler } \\
{[1-5 \text { days }]}\end{array}$ & $\begin{array}{l}{ }^{1} \text { Berner (1962), } \\
\text { Milliport, UK }^{(b)}\end{array}$ \\
\hline $722-1139$ & $12-42^{(\mathbf{a})}$ & $\begin{array}{l}\text { Over } \\
\text { night }\end{array}$ & $\begin{array}{c}30- \\
40\end{array}$ & $5-10$ & 10 & $\begin{array}{c}- \\
\text { [March- } \\
\text { July] }\end{array}$ & $\begin{array}{c}24-143 \\
{[80]}\end{array}$ & $\begin{array}{c}\text { Winkler } \\
{[40-50 \mathrm{hrs}]}\end{array}$ & $\begin{array}{l}{ }^{1} \text { Marshall \& Orr } \\
\text { (1966), } \\
\text { Milliport, UK }{ }^{(b)}\end{array}$ \\
\hline $\begin{array}{l}859- \\
1040\end{array}$ & $19-33^{(\mathbf{a})}$ & -(d) $^{-1}$ & 5 & $\begin{array}{c}29- \\
50\end{array}$ & 15 & $\begin{array}{c}7-8 \\
\text { [April - } \\
\text { May] }\end{array}$ & $116-142$ & $\begin{array}{c}\text { Barcroft-Dixon } \\
\text { Manometer } \\
{[3 \mathrm{hrs}]}\end{array}$ & $\begin{array}{l}{ }^{\mathrm{T}} \text { Raymont (1959) } \\
\text { Harvard, USA }\end{array}$ \\
\hline $804-1082$ & $16-36^{(\mathbf{a})}$ & - & 5 & 50 & 20 & $\begin{array}{l}5-10 \\
{[\text { Feb- }} \\
\text { June }]\end{array}$ & $\begin{array}{c}98-183 \\
{[130]}\end{array}$ & $\begin{array}{c}\text { Barcroft-Dixon } \\
\text { Manometer } \\
{[3 \mathrm{hrs}]}\end{array}$ & $\begin{array}{l}{ }^{\mathrm{I}} \text { Conover (1959), } \\
\text { Southampton, UK }\end{array}$ \\
\hline $700-1030$ & $11-32^{(\mathbf{a})}$ & - & 5 & $30-62$ & $10-20$ & - & $62-253$ & $\begin{array}{c}\text { Barcroft-Dixon } \\
\text { Manometer } \\
\text { [3-4 hrs] }\end{array}$ & $\begin{array}{l}{ }^{2} \text { Gauld \& Raymont } \\
\text { (1953), } \\
\text { Southampton, UK }\end{array}$ \\
\hline
\end{tabular}

(a) Dry weight estimated from the equation $\ln \mathrm{DW}=-15.9+2.79 \ln$ PL for T. longicornis (Castellani \& Altunbaş, 2006)

(b) Use of antibiotics streptomycin $\left(5 \mathrm{mg} \mathrm{l}^{-1}\right)$ and chloromycetin $\left(5 \mathrm{mg} \mathrm{l}^{-1}\right)$

(c) Measurements standardised to copepod of $1 \mathrm{~mm}$ in prosome length.

(d) Kept in lab for min. $24 \mathrm{hrs}$ before experiment.

(e) Author method supplemented with information from Razouls (1971) 